Int. J. Dev. Biol. 51: 633-647 (2007)

doi: $10.1387 /$ ijdb.072408js

\title{
Hair cell regeneration in the avian auditory epithelium
}

\author{
JENNIFER S. STONE ${ }^{1, *}$ and DOUGLAS A. COTANCHE ${ }^{2}$ \\ ${ }^{1}$ Virginia Merrill Bloedel Hearing Research Center, Department of Otolaryngology and Head and Neck Surgery, University of Washington \\ Seattle, WA and ${ }^{2}$ Department of Otolaryngology, Children's Hospital Boston, Department of Otology and Laryngology, Harvard Medical \\ School and Harvard-MIT Division of Health Sciences and Technology, Boston, MA, USA
}

\begin{abstract}
Regeneration of sensory hair cells in the mature avian inner ear was first described just over $\mathbf{2 0}$ years ago. Since then, it has been shown that many other non-mammalian species either continually produce new hair cells or regenerate them in response to trauma. However, mammals exhibit limited hair cell regeneration, particularly in the auditory epithelium. In birds and other non-mammals, regenerated hair cells arise from adjacent non-sensory (supporting) cells. Hair cell regeneration was initially described as a proliferative response whereby supporting cells re-enter the mitotic cycle, forming daughter cells that differentiate into either hair cells or supporting cells and thereby restore cytoarchitecture and function in the sensory epithelium. However, further analyses of the avian auditory epithelium (and amphibian vestibular epithelium) revealed a second regenerative mechanism, direct transdifferentiation, during which supporting cells change their gene expression and convert into hair cells without dividing. In the chicken auditory epithelium, these two distinct mechanisms show unique spatial and temporal patterns, suggesting they are differentially regulated. Current efforts are aimed at identifying signals that maintain supporting cells in a quiescent state or direct them to undergo direct transdifferentiation or cell division. Here, we review current knowledge about supporting cell properties and discuss candidate signaling molecules for regulating supporting cell behavior, in quiescence and after damage. While significant advances have been made in understanding regeneration in nonmammals over the last 20 years, we have yet to determine why the mammalian auditory epithelium lacks the ability to regenerate hair cells spontaneously and whether it is even capable of significant regeneration under additional circumstances. The continued study of mechanisms controlling regeneration in the avian auditory epithelium may lead to strategies for inducing significant and functional regeneration in mammals.
\end{abstract}

KEY WORDS: proliferation, transdifferentiation, cell cycle, cell fate, Notch, apoptosis, BrdU, Atoh1

\section{Introduction}

Sensory hair cells (HCs) are mechanoreceptors that are located in specialized epithelia in the inner ear and in lateral line neuromasts. A full complement of $\mathrm{HCs}$ in the auditory and vestibular epithelia of the inner ear is required for normal hearing and balance function. In humans, once auditory or vestibular HCs are damaged or lost, the resulting sensory deficits are permanent. Although deleterious changes occur in the auditory nerve and at higher levels following auditory $\mathrm{HC}$ loss, it is generally believed that restoration of healthy $\mathrm{HCs}$ could lead to substantial hearing improvements.

In mature mammals, regeneration of sensorineural structures and function after damage is uncommon. Exceptions include receptors in the olfactory receptor epithelium and in taste buds, which undergo continual turnover throughout life (e.g., for recent reviews, see Beites et al., 2005; Miura et al., 2006). Similar to the sensory epithelia of the inner ear, these cells are developmentally derived from surface ectoderm. In contrast, regeneration of sensory receptors and neurons derived from the neural tube (e.g., retinal ganglion neurons) or neural crest (e.g., dorsal root ganglion neurons) in mature mammals is atypical (but see Gould, 2007).

Several studies in experimental mammals have examined the inner ear's response to $\mathrm{HC}$ loss with the goals of finding evidence for initiation of $\mathrm{HC}$ regeneration or identifying ways to trigger the process. During development of the mouse auditory epithelium,

Abbreviations used in this paper: BP, basilar papilla; HC, hair cell; SC, supporting cell.

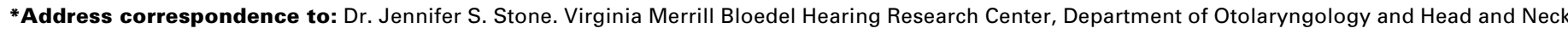

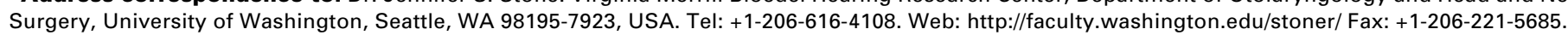
e-mail: stoner@u.washington.edu
} 
known as the organ of Corti, progenitor cell division has ceased by embryonic day 14.5 (Ruben, 1967; Lee etal., 2006; Matei etal., 2005). In adult mammals, the organ of Corti shows no spontaneous ability to form new HCs after noise or drug damage in vivo (e.g., Roberson and Rubel, 1994; Forge et al., 1998), although in vitro repair of injured HCs has been documented (Sobkowicz et al., 1997; Zheng et al., 1999). In contrast, the vestibular epithelium in adult rodents shows a small but significant increase in cell proliferation in response to HC damage in vivo(Rubel et al., 1995; Kuntz and Oesterle, 1998). The cells that divide (progenitor cells) are believed to be supporting cells (SCs), which are non-sensory cells that surround HCs in the sensory epithelia. Unfortunately, several studies show that in vivodifferentiation of newly produced cells into HCs is rare or non-existent (Rubel etal., 1995; Kuntz and Oesterle, 1998; Ogata et al., 1999; Oesterle et al., 2003, but see Forge et al., 1993).

In contrast to mammals, the post-embryonic replacement of damaged auditory and vestibular HCs is robust in many nonmammalian vertebrates. Early studies demonstrated that coldblooded animals, cartilaginous fish and toads, form new vestibular HCs as part of their normal body growth (Corwin, 1981; Corwin, 1985; Popper and Hoxter, 1984). In addition, HCs in the lateral line neuromasts are regenerated after tail amputation (Stone, 1933; Stone, 1937; Balak et al., 1990) or after laser-ablation of individual HCs (Jones and Corwin, 1993; 1996). Remarkably, avian species also form new HCs in vestibular epithelia on an ongoing basis in reaction to normal $\mathrm{HC}$ apoptosis (Jørgensen and Mathiesen, 1988; Roberson etal., 1992; Kil et al., 1997) and rates of regeneration are increased upon $\mathrm{HC}$ damage (Weisleder and Rubel, 1993). Regeneration of HCs in the avian auditory epithelium (also called the basilar papilla) occurs only in response to externally triggered $\mathrm{HC}$ trauma and death (Corwin and Cotanche, 1988; Ryals and Rubel, 1988; Oesterle and Rubel, 1993). Importantly, $\mathrm{HC}$ regeneration in birds occurs after $\mathrm{HC}$ epithelia and hearing function have matured. Morphological and functional recovery, including re-innervation, is rapid and thorough (reviewed in Cotanche, 1999; Smolders, 1999; Stone and Rubel, 2000a; Bermingham-McDonogh and Rubel, 2003).

In the late 1980s, two studies in post-hatch chickens initially demonstrated that birds have the capacity to regenerate HCs after they are damaged in the basilar papilla (BP; Cotanche, 1987a; Cruz et al., 1987). In these studies, two methods were used to induce $\mathrm{HC}$ damage; Cotanche exposed chickens to intense pure-tone noise, while Cruz et al. gave birds systemic injections with the ototoxic aminoglycoside antibiotic, Gentamicin. Pure-tone noise exposure creates relatively focal areas of $\mathrm{HC}$ damage and extrusion in corresponding tonotopic regions of the BP. In contrast, Gentamicin treatment induces complete $\mathrm{HC}$ loss in the high-frequency (proximal) end of the BP, starting at the proximal tip and moving toward the low-frequency (distal) end over time to encompass different total areas of the BP depending on the number of drug exposures (e.g., Hashino et al., 1991; Janas et al., 1995). In both studies, morphological analysis of the epithelium was performed at different times after $\mathrm{HC}$ damage. Cotanche (1987a) discovered that around 2 days (d) after the noise exposure had ended, cells with the appearance of embryonic $\mathrm{HCs}$ had emerged in the area of $\mathrm{HC}$ loss. These cells matured over the next 2 weeks and the normal cellular patterning of the BP was restored. Cruz etal. (1987) counted HCs at different times after Gentamicin treatment and discovered that HC numbers fell immediately but showed partial restoration by 3-4 weeks. Both studies interpreted their results to reflect the regeneration of sensory HCs, by an unknown mechanism that up to that point had not been considered feasible.

The discovery of $\mathrm{HC}$ regeneration in post-hatch birds raised considerable excitement about the potential for stimulating $\mathrm{HC}$ regeneration in adult mammals. Accordingly, some subsequent research has focused on identifying $\mathrm{HC}$ progenitors and on characterizing cellular and molecular mechanisms that direct $\mathrm{HC}$ regeneration in avian species, with the hopes that comparative studies in mammals might unveil critical differences between the two animal classes with respect to their response to $\mathrm{HC}$ loss. Here, we review the salient features of avian $\mathrm{HC}$ regeneration, with special emphasis on characteristics and regulation of $\mathrm{HC}$ progenitors in the BP.

\section{Avian supporting cells give rise to new hair cells through two distinct mechanisms}

Since initial reports by Cotanche and Cruz et al. in 1987, investigators explored cellular and molecular mechanisms employed by birds to regenerate new HCs in maturity. Seminal studies showed that new HCs arise through cell division of nonsensory supporting cells (SCs; Fig. 1), which are interspersed among HCs. In the BPs of chicken embryos, mitotic activity ceases by embryonic day 9 (Katayama and Corwin, 1989) and little or no cell division normally occurs after hatching (Oesterle and Rubel, 1993). However, exposure of post-hatch chickens or quail to intense noise stimulates SCs in the area of $\mathrm{HC}$ loss to leave growth-arrest and re-enter the cell cycle and the newly formed precursor cells then differentiate into HCs and SCs (Corwin and Cotanche, 1988; Ryals and Rubel, 1988). This was first demonstrated by delivery of the traceable nucleoside analog tritiated thymidine to birds following noise exposure in order to record proliferative activity. After $10 \mathrm{~d}$ of recovery, the nuclei of HCs and nearby SCs contained the analog, demonstrating they arose through renewed cell division. Subsequent studies went on to show that it is the SCs themselves, rather than an extrinsic cell type, that divide after $\mathrm{HC}$ damage in the $\mathrm{BP}$, whether due to noise exposure, drug treatment, or laser ablation of individual HCs (Raphael, 1992; Hashino and Salvi, 1993; Stone and Cotanche, 1994; Stone et al., 1999; Warchol and Corwin, 1996). SCs also serve as $\mathrm{HC}$ progenitors during regeneration of the avian vestibular epithelium (Jørgensen and Mathiesen, 1988; Roberson et al., 1992) and during regeneration of all $\mathrm{HC}$-epithelia and neuromasts in other non-mammalian vertebrates (e.g., Balak et al., 1990; Yan et al., 1991; Baird et al., 1993). Analysis of avian sensory epithelia after $\mathrm{HC}$ damage revealed that, as SCs traverse from growth arrest to mitosis, their nuclei migrate from their normal position near the basal lamina to the lumenal surface (Raphael, 1992; Tsue et al., 1994; Fig. 1). Precursors born at the lumen then undergo specific nuclear translocation and differentiation of cytoplasmic and apical features depending on the cell fates they acquire (Stone et al., 1996; Stone and Rubel, 2000b; Roberson et al., 2004; Duncan et al., 2006).

$\mathrm{SC}$ division is not the sole means for generating new $\mathrm{HCs}$ in non-mammalian vertebrates; SCs also have the ability to spontaneously convert into HCs (Fig. 1) via a process called direct 
transdifferentiation. While there are many examples of differentiated cell types that alter their phenotypes to stably acquire another differentiated state (transdifferentiation), this process usually involves transit through the cell cycle (e.g., Nathanson, 1986). In contrast, direct transdifferentiation occurs without cell cycle re-entry (Beresford, 1990). For example, neural retina can directly convert into lens cells in embryonic chickens (Opas and Dziak, 1998). There is significant evidence for $\mathrm{HC}$ regeneration via direct transdifferentiation from SCs in mature amphibian saccules and avian BPs. After ototoxic drug treatment, HC numbers are restored in cultured saccules from frogs and newts despite continuous inhibition of SC division by the S-phase blocker, Aphidicolin (Baird et al., 1996; Baird et al., 2000; Taylor and Forge, 2005). A similar finding was reported in the chicken BP after HC damage (Adler et al., 1996), although inhibition of SC division was only transient. Roberson et al. (1996) implanted a pump to continuously deliver a traceable nucleoside analog (bromodeoxyuridine or tritiated thymidine) into the chicken peri-

A

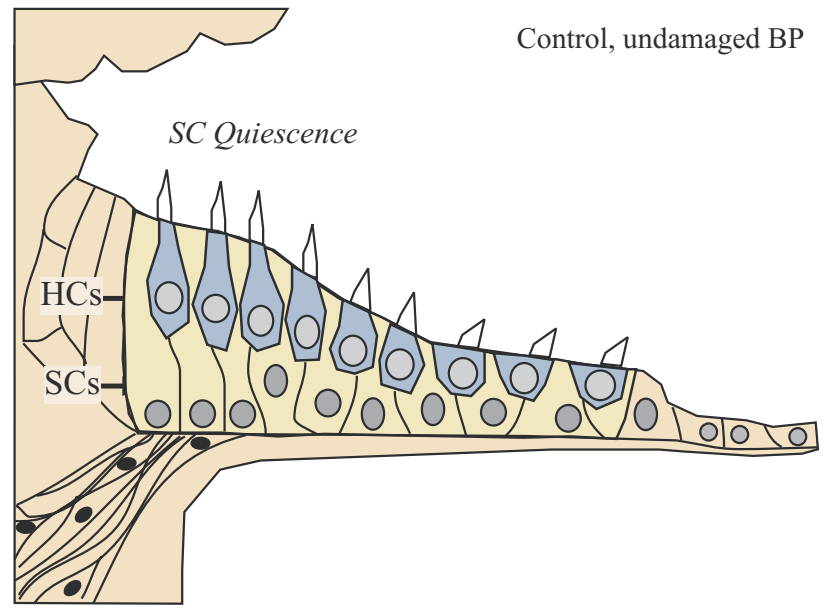

B

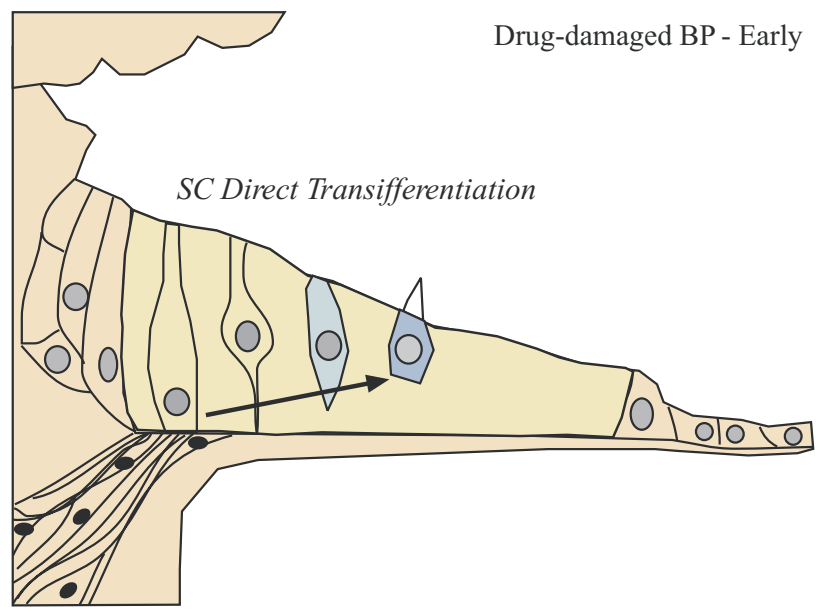

lymph and subsequently administered Gentamicin to trigger $\mathrm{HC}$ loss. At $12 \mathrm{~d}$ post-Gentamicin, only $50 \%$ of regenerated $\mathrm{HCs}$ had incorporated the nucleoside, while the other half had not. In a similar study, at $10 \mathrm{~d}$ post-Gentamicin, $70 \%$ of regenerated HCs showed incorporated nucleoside while $30 \%$ did not (Roberson et al., 2004). Since the HC lesion was complete in the area of analysis, $\mathrm{HC}$ repair was ruled out as an explanation of the finding. Rather, since the mitotic tracer was available to SCs before, during and after $\mathrm{HC}$ death, the result suggested that a subpopulation of SCs phenotypically converted directly into HCs without dividing. Further evidence for SC transdifferentiation into HCs was provided by a recent study showing that Atoh1, a proneural transcription factor whose translation during organ of Corti development is thought to be limited to early differentiating HCs (Chen et al., 2002; Woods et al., 2004; Matei et al., 2005), becomes highly expressed in the nuclei of SCs shortly after $\mathrm{HC}$ damage and is later highly expressed in regenerated HCs (Cafaro et al., 2007). These studies provide strong evidence that direct transdifferentiation is a significant source of new HCs during avian $\mathrm{HC}$ regeneration.

The first new $\mathrm{HC}$ s to emerge after $\mathrm{HC}$ damage are produced by direct transdifferentiation, while new HCs generated by mitosis appear later and eventually comprise a substantial proportion of the new sensory cells (Roberson et al., 1996; Roberson et al., 2004; Cafaro et al., 2007). Transdifferentiating SCs are detected as early as 15 hours (h) after Gentamicin treatment, prior to the extrusion of HCs in the region (Cafaro et al., 2007). Thus, SCs are activated to transdifferentiate in response to cues that occur shortly after HC damage is initiated. Significant numbers of SCs in the damaged region enter S phase around 72h (Bhave et al., 1995; Stone et al., 1999; Roberson et al., 2004; Duncan et al., 2006). At this time, there are already regenerated HCs present in the region where $\mathrm{SC}$ division occurs, as illustrated by labeling with early $\mathrm{HC}$ antigens (e.g., MyosinVI and TuJ1; Stone and Rubel, 2000b; Roberson et al., 2004). However, none of these firstappearing regenerated $\mathrm{HCs}$ is derived from newly post-mitotic

C

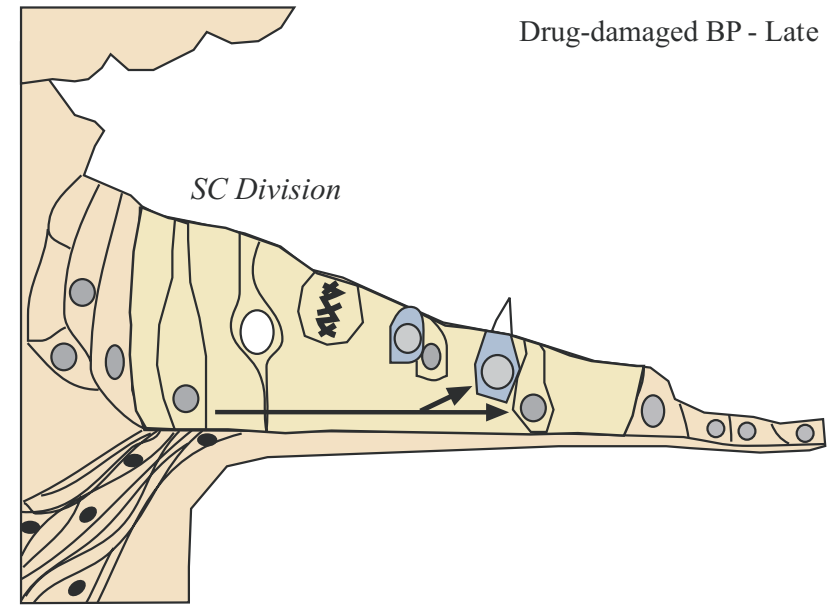

Fig. 1. Supporting cell behaviors in the chicken basilar papilla. These schematics depict supporting cells (SCs) in the mature chicken basilar papilla $(B P)$ in different states. (A) SCs in quiescence in an undamaged BP. Hair cells (HCS). (B,C) SCs in the drug-damaged BP undergoing either direct transdifferentiation (B) or cell division (C). In (B,C), arrows indicate the temporal progression of each SC response, starting with a single SC on the left and ending in a single new HC on the right (B, direct transdifferentiation) or starting with a single SC on the left and ending in two new cells (a $H C$ and a SC here) on the right (C, cell division). Abbreviations: BP, basilar papilla; HC, hair cell; SC, supporting cell. 
cells (Roberson etal., 2004). Rather, HCs regenerated via mitosis are not detected by antibodies to early $\mathrm{HC}$-specific antigens until around 96h (4d; Fig. 2) and by later antigens, such as MyosinVIIa, until $120 \mathrm{~h}(5 \mathrm{~d})$. The number of $\mathrm{HCs}$ formed by direct transdifferentiation peaks at $144 \mathrm{~h}(6 \mathrm{~d})$ and remains unchanged at $240 \mathrm{~h}(10 \mathrm{~d})$, whereas the number of mitotically regenerated HCs increases significantly after $5 d$, so that by $10 d$, they comprise 50 $70 \%$ of the new HCs (Roberson et al., 1996; Roberson et al., 2004). These data indicate that the first new HCs created during the early stages of regeneration are produced by direct transdifferentiation and that later, when more HCs are lost, mitosis takes over to produce additional new HCs. Once mitosis is initiated, direct transdifferentiation is down-regulated, so that by $10 \mathrm{~d}$, most HCs present in the epithelium have been derived through cell division. However, signals that regulate the initiation of direct transdifferentiation and stimulate the switch to mitosis are not yet identified (discussed below).

In addition to this temporal separation of non-mitotic and mitotic regeneration, SCs in different regions along the width-wise axis of the BP are more likely to give rise to new HCs using one mechanism rather than another. Cafaro et al. (2007) showed that, after Gentamicin treatment, the density of dividing SCs is much higher in the neural half of the epithelium than in abneural half. Further, the majority ( $81 \%$ ) of regenerated HCs in the neural half of the BP are formed by SC division while in the abneural half, the majority (66\%) of new HCs are formed by direct transdifferentiation. Since the timing, mechanism and degree of $\mathrm{HC}$ loss are essentially the same in these two regions of the $\mathrm{BP}$, this observation likely reflects intrinsic differences in SCs in each region or divergence in local signals.

\section{Properties of avian supporting cells}

Unlike HCs, whose cell bodies are confined to the lumenal region of the sensory epithelium, most SCs have elongated cell bodies that appear to contact both the lumenal and basal surfaces of the epithelium. When quiescent, SC nuclei are typically located basal to HC nuclei. Ultrastructural studies show that SCs of the avian BP are fairly undifferentiated, with poorly developed cytoskeletons and a low density of organelles (e.g., Takasaka and Smith, 1971; Hirokawa, 1978; Hirose et al., 2004). In fact, a study of the fish saccule demonstrated that actively dividing SCs bear high resemblance to quiescent SCs with respect to their gross and fine morphological features (Presson et al., 1996). Nonetheless, in the avian BP, SCs serve many functions, including production of extracellular matrix for the overlying tectorial membrane (Cotanche, 1987b; Epstein and Cotanche, 1995; Killick et al., 1995; Goodyear et al., 1996; Coutinho et al., 1999), establishment of a pathway for potassium clearance via gap junctions (Wangemann, 2002; Forge et al., 2003; Nickel et al., 2006), neurotrophic support of HCs and neurons (Stankovic et al., 2004) and anchoring of the sensory epithelium to the basilar membrane (Cotanche et al., 1992; Cotanche et al., 1995). As discussed above, after HC damage, some SCs display behaviors characteristic of progenitors, undergoing cell division, while others resemble precursor cells, forming new HCs through staged transdifferentiation. Quantitative analyses after ototoxic $\mathrm{HC}$ damage demonstrate that approximately $1 / 4$ of SCs divide, 1/4 of SCs transdifferentiate and $1 / 2$ of SCs exhibit neither response
(Roberson et al., 1996). It is logical that these SCs responses must be balanced in order to establish the proper number and type of new cells in the BP while maintaining important SC functions. Thus, a critical question is how individual SCs are instructed to select each response. One possibility is that subsets of SCs are restricted to behave only as stem/progenitor cells or precursor cells poised for transdifferentiation and the remaining SCs are terminally differentiated and incapable of either response. Alternatively, all SCs may have equivalent potential, but subpopulations respond in a given manner due to locally regulated signals. If the former is true - that SCs are specialized - then subsets of SCs with distinct properties should be identifiable, but to date, few studies have directly addressed this issue. A cell lineage study revealed two distinct $S C$ shapes in the late embryonic $B P$, which is nearly mature (Fekete et al., 1998). A small subpopulation of SCs (4\%) had a basally located nucleus and a thin cytoplasmic process leading to the lumenal surface. The remaining SCs that were observed had a thicker appearance, with a nucleus located more lumenally. This is an intriguing observation, particularly because approximately $4 \%$ of SCs show stem cell-like behavior during regeneration, dividing more than once (Stone et al., 1999). However, it remains to be demonstrated that SCs with the delicate appearance are in fact stem cells. In the quiescent BP, several molecular markers appear to label all SCs (e.g., Kruger et al., 1999). However, only a few markers define subsets of SCs. For example, Bhave et al. (1995) found that $3 \%$ of quiescent SCs express detectable levels of proliferating cell nuclear antigen (PCNA). In addition, SCs across the neural-abneural axis of the BP express different levels of the transcription factor Prox1 (Stone et al., 2004) or transcripts for fibroblast growth factor receptor 3 (Bermingham-McDonogh et al., 2001). The functional significance of these different expression profiles has not been established. However, given the different degrees of SC division seen in the neural and abneural regions of the BP after $\mathrm{HC}$ loss (Cafaro et al., 2007), it is tempting to hypothesize that these molecules play a role in regulating cell cycle progression or stem cell properties in SCs.

Which properties might render SCs likely to respond in one manner or another? Molecular analyses demonstrate that mature SCs are not simply progenitor cells retained from development. For example, the transcription factor Prox 1 is detectable in all progenitor cells in the sensory epithelia of the chick otocyst as they are dividing (Stone et al., 2003). But, in the BP, Prox1 protein is downregulated in SCs as post-mitotic cells differentiate, such that by hatching, only a subpopulation of SCs in the neural half express detectable levels of the protein. While the function of Prox1 in the BP remains to be determined, homologues of Prox1 are required for proliferative activity and cell lineage decisions in fruit flies (e.g., Reddy and Rodrigues, 1999) and mice (e.g., Wigle and Oliver, 1999; Dyer et al., 2003). Thus, one possibility is that SCs that retain Prox1 expression in maturity are embryonic-like and more apt to respond by dividing. This may also be true of SCs that express high levels of PCNA (Bhave et al., 1995). At this point, however, the relative homogeneity of SCs favors the interpretation that a SC responds in a given way not due to its degree of specialization but rather in response to distinct cues encountered in its microenvironment (Morest and Cotanche, 2004). Analyses in other tissues have stimulated investigators to theorize that direct transdifferentiation occurs because of shifts in 


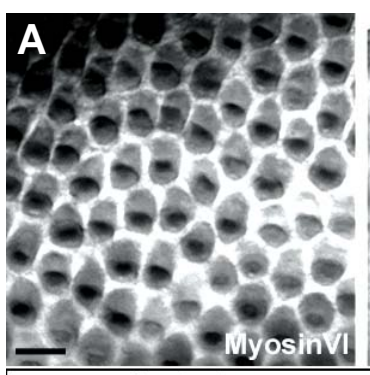

Control

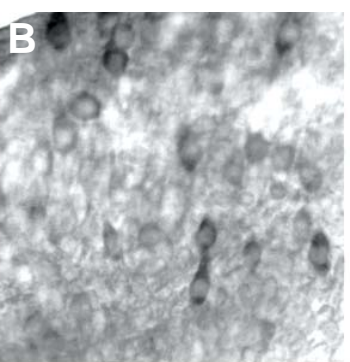

4 days post-gentamicin

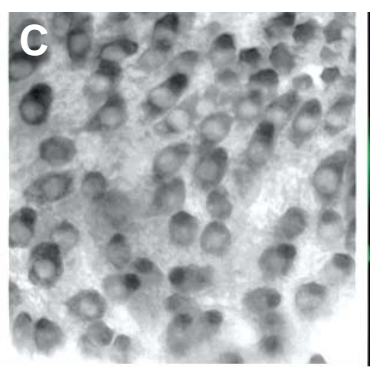

8 days post-gentamicin

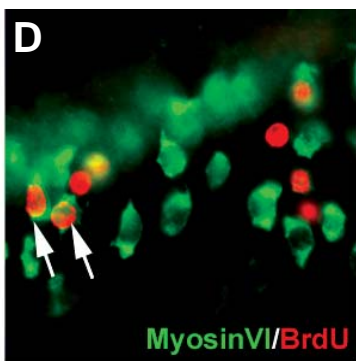

7 days post-gentamicin 3 days post-BrdU

Fig. 2. Hair cell regeneration after drug damage in the chicken basilar papilla. The proximal end of the basilar papilla (BP) is shown in whole-mount preparations in all panels. Panels (A-C) show immunolabeling for the hair cell (HC)-specific protein, MyosinVI (gray), in the control, undamaged BP (A), in the BP at 4 days post-Gentamicin (B) and in the BP at 8 days post-Gentamicin (C). The apical surfaces of normal mature HCs (A) appear round. At 4 days post-Gentamicin (B), note the loss of mature HCs in the proximal region and the reemergence of new, immature HCs with fusiform cell shapes. By 8 days post-Gentamicin, more new HCs have emerged and they appear more mature. (D) Double-labeling for MyosinVI (green) and BrdU (red). BrdU was applied as a single pulse at 4 days post-Gentamicin and animals were euthanized 3 days post-BrdU, at 7 days post-Gentamicin. Hair cells formed by mitosis are double-labeled (arrows). Scale bar, $10 \mu \mathrm{m}$.

intrinsic properties of progenitors in response to microenvironmental changes (discussed in Opas and Dziak, 1998). Future experiments in the chicken BP should aim to characterize molecular profiles associated with each SC behavior after $\mathrm{HC}$ death.

\section{Avian supporting cells respond to the progression of hair cell death}

In the normal post-hatch BP, SCs are in a state of quiescence; there is no mitotic activity and no evidence for ongoing transdifferentiation. Shortly after $\mathrm{HC}$ damage is initiated, SCs are activated to alter this quiescence. Somewhat surprisingly, this response is not limited to the area of ultimate HC loss. Rather, SCs throughout the entire sensory epithelium, including in areas that are a millimeters from where $\mathrm{HC}$ loss will occur, progress from growth arrest to $\mathrm{G} 1$, an early phase of the cell cycle (Bhave et al., 1995). Therefore, an early signal triggering a change in SC properties is globally distributed throughout the BP. However, SCs that show clear signs of transdifferentiating as HCs and SCs that undergo DNA synthesis and divide, are only seen near where HC loss will occur or is occurring (Corwin and Cotanche, 1988; Raphael, 1992; Stone and Cotanche, 1994; Cafaro et al., 2007). Therefore, critical local signals regulate the ultimate behavior of SCs after HC damage in the avian BP.

What might these global and local signals be? One strategy for identifying potential regulators of SC behavior in the chicken BP is to identify specific steps in cellular injury and death during sound-damage or Gentamicin-damage in the avian cochlea and to correlate each step with specific regenerative responses in nearby or distant SCs (e.g., Torchinsky et al., 1999; Hirose et al., 2004; Mangiardi et al., 2004; Dai et al., 2006; Duncan etal., 2006; Warchol and Speck, 2007). It appears that damaged HCs undergo apoptosis, which is a carefully orchestrated genetic program that results in a cell deliberately killing itself (Kerr et al., 1972; Wyllie, 1980). Apoptosis is thought to involve three phases: initiation, arbitration and execution. Initiation is defined as the internal damage or external signal that starts the cell death program. Once apoptosis is initiated, there is a period of arbitration where cell survival signals compete with the cell death signals in an attempt to rescue the cells. If the death signals dominate at this stage, the cell dies; but if the survival signals dominate, the cell lives. It is not clear at this point which specific changes in $\mathrm{HCs}$ occur early enough to result in the initiation of transdifferentiation in nearby SCs. For many cell types, the execution stage of the pathway involves the release of Cytochrome $\mathrm{C}$ from mitochondria and the activation of Caspase-3 (McDonald and Windebank, 2000; Bouchier-Hayes et al., 2005). This subsequently mobilizes a regulated enzyme cascade that results in the breakdown of multiple cellular components and eventual cell death. The most prominent and well-studied components of the execution phase are Caspases (Cryns and Yuan, 1998; Thornberry and Lazebnik, 1998; Earnshaw etal., 1999 Lavrik etal., 2005). Specific Caspases are thought to be involved in the early, upstream phase, such as Caspases 8, 9 and 10, while others are restricted to the later, downstream stages, such as Caspases 3, 6 and 7 .

Gentamicin enters HCs shortly after a single systemic injection (by 6h; Dai et al., 2006). Initially, Gentamicin is detected in the most proximal $\mathrm{HCs}$, but by $9 \mathrm{~h}$, it has accumulated in HCs throughout the BP. SCs show no evidence of Gentamicin uptake, suggesting that changes in SC behaviors are not caused by cellautonomous effects of the drug. Following a single Gentamicin injection, $\mathrm{HCs}$ first begin to be ejected from the proximal tip of the $\mathrm{BP}$ at $30 \mathrm{~h}$, or $24 \mathrm{~h}$ after the Gentamicin first reaches these HCs. Hair cell loss progresses down the cochlea to encompass the proximal $30 \%$ of the BP by $42 \mathrm{~h}$ and by $54 \mathrm{~h}$, all HCs have been ejected from this region (Mangiardi et al., 2004). The lack of Myosin-labeled cells within the proximal $30 \%$ of the BP by $54 \mathrm{~h}$ demonstrates that no surviving HCs remain in the Gentamicindamaged region of the BP.

The first indication that damaged HCs are undergoing apoptosis appears at $12 \mathrm{~h}$ post-Gentamicin, with the translocation of Tcell restricted intracellular antigen-related (TIAR) protein from the nucleus into the cytoplasm of HCs in the proximal tip of the BP. Cellular translocation of TIAR is an early indicator of apoptosis in many tissues (Taupin et al., 1995). This step occurs 6h after Gentamicin first enters the $\mathrm{HCs}$ and $18 \mathrm{~h}$ before $\mathrm{HCs}$ will be ejected from the sensory epithelium. No changes in TIAR location have been detected in areas where $\mathrm{HC}$ loss and regeneration will 
not occur (e.g., in the distal half after Gentamicin treatment). TIAR translocation is the only known molecular sign that the HCs have entered the apoptotic cascade at this early time-point. Since TIAR translocation occurs around the time that SCs begin to show overt signs of transdifferentiating (Cafaro et al., 2007), it is intriguing to hypothesize that TIAR translocation may in some way be connected with early signals that trigger SC transdifferentiation. While TIAR appears to be involved in the formation of stress granules in damaged cells (Kedersha et al., 2000), the specific downstream molecules that it regulates are not known.

Two additional apoptosis-associated events occur in $\mathrm{HCs}$ around $30 \mathrm{~h}$ post-Gentamicin, as HCs are just beginning to be ejected from the BP: the release of Cytochrome $\mathrm{C}$ from mitochondria into the cytoplasm and the activation or cleavage of Caspase3 (Mangiardi et al., 2004; Cheng et al., 2003). Release of Cytochrome $\mathrm{C}$ and Caspase- 3 activation are both first seen in the proximal end and spread distally over time, as the $\mathrm{HC}$ lesion increases in size. Neither response occurs in areas where HC loss and regeneration will not occur. These changes occur prior to the initiation of SC re-entry into cell cycle and therefore may be part of the cascade of events leading to SC division.

Recent studies have used inhibitors of the apoptotic pathway to block ongoing or drug-induced $\mathrm{HC}$ cell death in the avian vestibular epithelium in vivo (Matsui et al., 2002; Matsui et al., 2003; Matsui et al., 2004) and in the mammalian utricle and chick $\mathrm{BP}$ in vitro following aminoglycoside treatment (Cunningham et al., 2002; Cheng et al., 2003; Sugahara et al., 2006). These studies suggest that inhibiting steps in the cell death pathway can block apoptosis in HCs. It would be interesting to determine how $\mathrm{SC}$ responses progress in these cases, in which $\mathrm{HC}$ damage is initiated but survival signals predominate, preventing $\mathrm{HC}$ death. Another important area of study is the distal end of the BP, where HCs undoubtedly are affected by short Gentamicin treatments but ultimately survive. While it has been demonstrated that distal SCs initiate transition from quiescence into the cell cycle (Bhave et al., 1995), it is not clear if distal SCs begin steps toward transdifferentiation. It is of particular interest to determine how $\mathrm{HCs}$ and SCs are differentially altered in the proximal and distal ends of the BP after Gentamicin treatment, because such information could help to identify the extent of $\mathrm{HC}$ damage required to initiate SC withdrawal from quiescence and progression toward transdifferentiation or cell division.

\section{Signals directing a SC's pathway for regeneration}

Which signals regulate $\mathrm{SC}$ quiescence and activation after $\mathrm{HC}$ loss? One working hypothesis is that direct transdifferentiation is the principal route for regenerating $\mathrm{HCs}$ and that $\mathrm{SC}$ division occurs only to repopulate depleted SCs after they have converted to HCs (Roberson et al., 2004). In this model, the loss of SCs that accompanies the initial transdifferentiation phase of regeneration may trigger adjacent SCs to divide. This hypothesis represents an interesting divergence from the classical idea that normal HCs laterally inhibit SC division (e.g., Corwin and Cotanche, 1988). However, this hypothesis is currently difficult to test because there is no known tool for experimentally blocking direct transdifferentiation.

Regardless of the signals' source, the following signals must be critical for regulating SC behavior: those that maintain SCs in a differentiated quiescent state (preventing transdifferentiation and division), those that trigger SC transit from quiescence toward transdifferentiation or division and those that assure only a limited number of SCs respond to active signals. Clues toward identifying these signals may be derived from our knowledge of pathways that direct the initial development of inner ear epithelia. Several molecular pathways are known to regulate embryonic $\mathrm{HC}$ progenitors and some of these pathways are reactivated in mature $\mathrm{HC}$ epithelia after $\mathrm{HC}$ loss and therefore may be important in directing SC behavior. Sensory epithelia, including the BP, form from the otic placode, a specialized region of ectoderm. During embryogenesis, the placode undergoes growth, morphogenesis and differentiation, establishing specific auditory or vestibular epithelia as well as non-sensory structures. Induction of the otic placode is controlled by several molecules, including Wnts and Fibroblast Growth Factors (reviewed in Fekete and Wu, 2002; Brown et al., 2003). After induction, placodal cells express distinct sets of transcription factors and later, as the otic epithelium develops, distinct regional patterns of gene expression emerge. Specification of regions as sensory patches is associated with expression of bone morphogenetic proteins (BMPs 4 and 7 ; Wu and Oh, 1996; Cole et al., 2000), Notch-associated genes (Serrate1, Lunatic Fringe [Lnfg], Notch1 and Delta1; Adam et al., 1998; Cole et al., 2000) and some transcription factors (e.g., Prox1, Atoh1 [Stone et al., 2003] and Sox2 [Kiernan et al., 2005; Neves et al., 2007]. Since mature SCs in the avian BP are distinct from embryonic progenitors, it is of great interest to determine if SCs must transit to an immature state (dedifferentiate) before they can divide or directly transdifferentiate into HCs. If this were the case, SCs would show regressive changes in their genetic profiles after $\mathrm{HC}$ damage. Analysis and perturbation of genes expressed in embryonic progenitors (e.g., Prox1, BMP4, Serrate 1 , or $L n f g$ ) could provide insight into this question. It would also be important to identify anchored or diffusible signaling molecules that regulate such regressive genetic changes in SCs, as they are likely required for regeneration. In mature mammals, regeneration of $\mathrm{HCs}$ may fail because SCs are inhibited from dedifferentiating, they are unable to respond to signals promoting dedifferentiation, or signals promoting regression are lacking.

In the mature chicken BP after HC loss, the basic helix loop helix (bHLH) proneural transcription factor Atoh1 (atonal, Ath1; Jarman et al., 1993; Ben-Arie et al., 2000) becomes reactivated in transdifferentiating and mitotically active SCs (Cafaro et al., 2007). Atoh1 has a critical function in $\mathrm{HC}$ development, which has been best studied in the mouse inner ear. There, loss of Atoh1 (Math1) leads to failed specification and/or differentiation of HCs (Bermingham et al., 1999; Woods et al., 2004; Matei et al., 2005). SCs also fail to differentiate, but this may occur as a result of failed $\mathrm{HC}$ development rather than in direct response to Atoh1 deletion (Woods et al., 2004). Similarly, knockdown of Atoh1a and/or Atoh $1 b$ in zebrafish results in the production of fewer inner ear HCs (Millimaki et al., 2007). During development, Atoh1 expression emerges in sensory patches (Bermingham et al., 1999; Stone et al., 2003; Woods et al., 2004; Matei et al., 2005), becomes highly elevated in $\mathrm{HCs}$ after terminal mitosis (Chen et al., 2002; Lumpkin et al., 2003) and is down-regulated after HC differentiation (Lanford et al., 2000; Zheng et al., 2000). Misexpression of Atoh 1 in the inner ear of developing or mature rodents leads to ectopic HC differentiation (Zheng and Gao, 2000; 
Kawamoto etal., 2003; Shou etal., 2003; Izumikawa etal., 2005). In the mature undamaged chicken BP, Atoh1 protein is not detected in HCs or SCs (Cafaro et al., 2007). However, within hours of $\mathrm{HC}$ damage, while $\mathrm{HCs}$ are still intact, Atoh1 protein becomes detected in the nuclei of SCs in the proximal, damaged end of the BP. Later, Atoh1 protein is seen in regenerated HCs. During development of the chicken otocyst, Atoh 1 transcripts are not detected in progenitor cells but rather, they seem to first emerge in differentiating HCs (Pujades et al., 2006). Thus, it seems unlikely that upregulation of Atoh1 in activated SCs represents a return to an immature progenitor-like state. Nonetheless, given Atoh1's critical role in regulating $\mathrm{HC}$ specification and/or differentiation in rodents, Atoh1 probably directs the $\mathrm{SC}$ to $\mathrm{HC}$ fate switch during regeneration in the chicken BP. Therefore, it is of great interest to determine how Atoh1 expression is regulated in quiescent and activated SCs and whether changes in Atoh1 activity are sufficient to direct one SC behavior or another. One study - Cafaro et al., 2007 - shows that elevated expression of Atoh1 in SCs or in post-mitotic precursor cells is not sufficient to irreversibly specify that cell as a HC. Rather, Atoh1 expression is highly dynamic in some post-mitotic cells during the first 24-48h after it is upregulated and some of the cells that initially show high levels of Atoh1 protein go on to differentiate as SCs. Therefore, cell fate specification is a complex process that likely depends on several inputs from cells in the epithelia microenvironment.

Regulation of atonall Atoh/transcription is combinatorial; atonal/ Atoh1 (e.g., Helms et al., 2000), Ngn1 (Gowan et al., 2001), Wingless/Wnt (e.g., Niwa et al., 2004), Decapentaplegic/BMPs (e.g., Niwa et al., 2004), epidermal growth factor (zur Lage et al., 2004), fibroblast growth factor (e.g., Millimaki et al., 2007) and
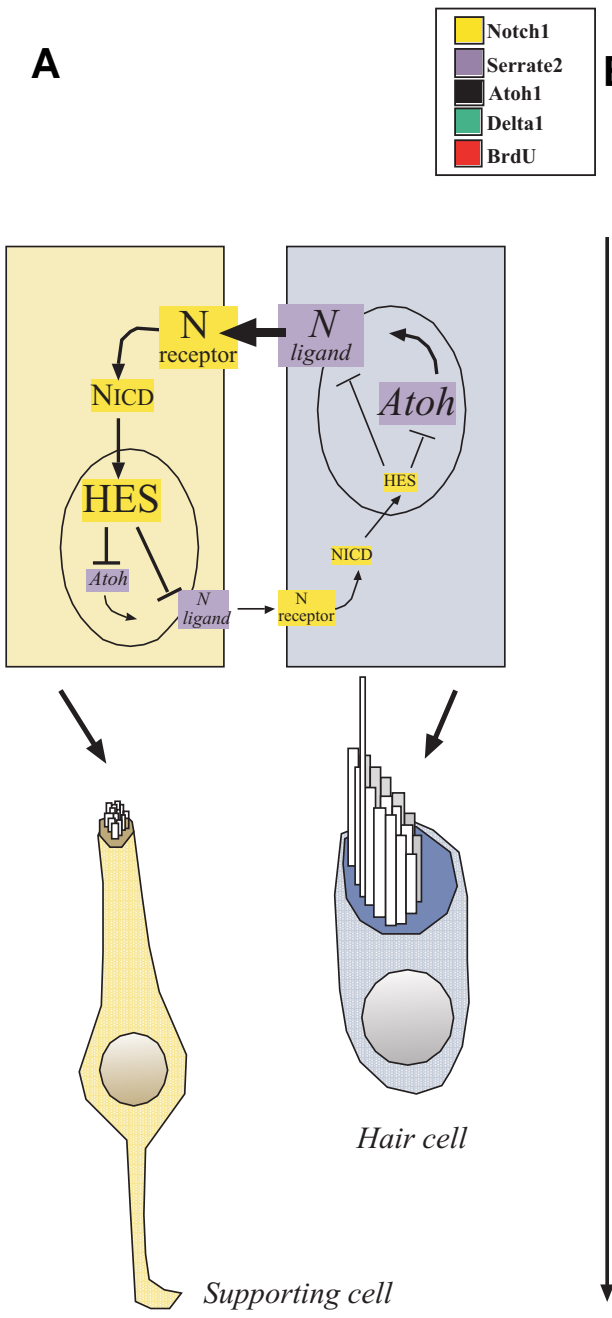

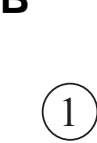

1)

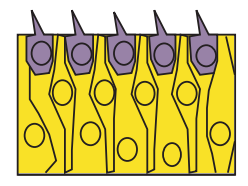

(2)
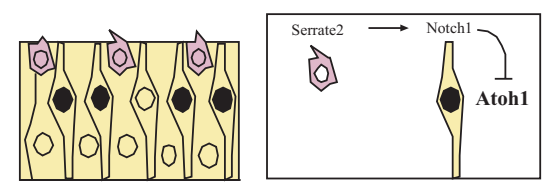

(3)
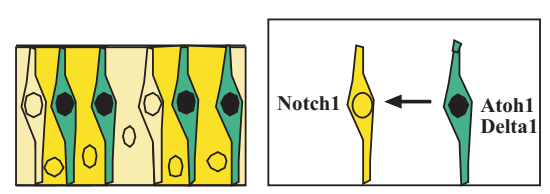

(4)
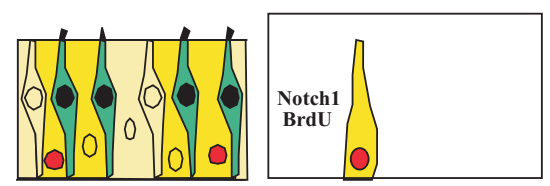

(5)
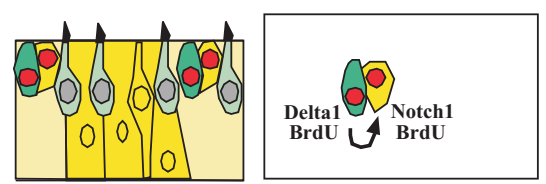

$\downarrow$

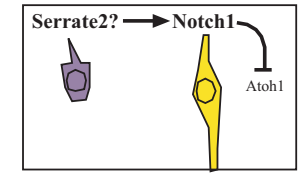

Fig. 3. Notch signaling in hair cell epithelia. (A) Major molecules involved in the Notch signaling pathway and how they cooperate in two adjacent cells to lead to the production of different cell types, a supporting cell and a hair cell in this case. The cell on the right (purple) is the "signaling cell". Its relatively high levels of Notch (N) ligand bind and activate $\operatorname{Notch}(N)$ receptors on the cell on the left (yellow), the "receiving cell. As a result, Notch activation is high in the receiving cell and high levels of the Notch intracellular domain (NICD) are released from the membrane and travel to the nucleus. As a result, HES repressor activity is increased and transcription of Atoh1 and $\mathrm{N}$ ligand is inhibited. In response, the receiving cell's ability to activate $\mathrm{N}$ receptor on the signaling cell is diminished and transcription of Atoh1 and N ligand becomes increased in the signaling cell due to low HES repressor activity. In this manner, signaling cells acquire the sensorineural fate $(H C)$ and receiving cells acquire a non-sensory fate (SC). (B) A working model for how Notch signaling progressively alters SC behaviors in the chicken basilar papilla after HC damage, with stages numbered and later stages shown at lower levels in the figure. On the left, progressive changes in gene expression patterns are shown. On the right, the pertinent signals regulating/reflecting SC behavior at a given time are shown. 1) In the mature, undamaged $B P$, Notch ligand

(Serrate2?) expressed in HCs activates Notch1 in SCs, maintaining them in a quiescent state. 2) After ototoxin treatment, HCs are damaged and lose Notch ligand function; in nearby SCs, Notch1 activity is decreased and Atoh1 levels are increased. 3) Atoh1-positive SCs begin to transdifferentiate and upregulate Delta1; increased Notch1 activity in some SCs prevents them from expressing Atoh1 and initiating direct transdifferentiation. 4) SCs with increased Notch activity either undergo cell division (incorporate BrdU) or remain mitotically quiescent; Delta1/Atoh 1-positive cells continue to differentiate as HCs. 5) Some post-mitotic cells upregulate Atoh1 and Delta1 (shown) and activate Notch1 in other post-mitotic cells (siblings?); transdifferentiated HCs down-regulate Delta1 and Atoh1. 6) Delta1/Atoh1-positive post-mitotic cells differentiate as HCs; neighboring cells with high Notch1 activity differentiate as SCs; transdifferentiated HCs approach maturity and reexpress Serrate2. 
Notch (e.g., Baker et al., 1996) are all examples of molecules thought to exert direct or indirect influence on atonal/Atoh1 transcription. Of these, Notch has been most thoroughly studied in the vertebrate inner ear. Notch's role in limiting expression of atonal/Atoh 1 is effectively illustrated by its role in fruit fly sensory organ development. Initially, all progenitor cells in sensory primordia express atonal. Over time, atona/becomes limited to specific cells that will acquire sensory or neural fates (e.g., Baker et al., 1996; Baker and Yu, 1997). Initially, Notch activity is required for atona/transcription in cells across the sensory primordium. Later, Notch activity restricts atona/ transcription to limited cells. Repression of proneural genes such as atonal occurs through another bHLH transcription factor called Hairy/Enhancer of Split (HES; Heitzler et al., 1996). HES's repressor activity becomes activated when the Notch receptor is bound by one of its ligands, Delta or Serrate (Artavanis-Tsakonas and Simpson, 1991; Muskavitch, 1994), which are located on adjacent cells. When bound, a portion of Notch is released from the membrane and moves into the nucleus, where it alters HES function (Fig. 3A). A similar transduction pathway occurs in mammals (reviewed in Selkoe and Kopan, 2003; Kageyama et al., 2005). Since HES and atonal/Atoh1 have opposing effects on transcription of Notch ligands, (Kageyama et al., 1995; Heitzler et al., 1996), adjacent cells ultimately require different levels of atonal/Atoh 1 and therefore, distinct fates.

During $\mathrm{HC}$ development in the vertebrate inner ear, Notch plays several important roles (Lewis, 1996; Kelley, 2006). In the early otocyst, activation of a Notch receptor by Jagged1 (analogous to Serrate1 in chick and fruit flies) is required for specifying regions of the otic epithelium as "sensory". Either loss of Jagged1 in mice (Kiernan et al., 2001; Kiernan et al., 2006) or complete inhibition of Notch activity with the pharmaceutical inhibitor DAPT in chickens (Daudet et al., 2007) causes decreased size or loss of sensory patches. In contrast, misexpression of the Notch intracellular domain in chickens leads to the formation of ectopic sensory patches (Daudet and Lewis, 2005). Later, as sensory epithelia differentiate, signaling through Notch regulates cell fate specification, primarily by inhibiting the $\mathrm{HC}$ fate. Disruption of Notch1 receptor, Jagged2/Delta-1-like, or downstream effector function leads to premature differentiation and overproduction of HCs (Haddon et al., 1998; Lanford et al., 1999; Riley et al., 1999; Lanford et al., 2000; Zhang et al., 2000; Zheng et al., 2000; Zine etal., 2000; Kiernan etal., 2001; Tsai etal., 2001; Zine etal., 2001; Kiernan et al., 2005; Brooker et al., 2006), as well as limited transdifferentiation of SCs into HCs (Yamamoto et al., 2006). Thus, as expected given Notch's antagonism of Atoh1, loss of Notch1 activity generates the opposite phenotype as seen with Atoh1 deletion (Bermingham et al., 1999). Notch1's negative regulation of Atoh1, mediated by HES1/5, is a likely mechanism for its inhibition of $\mathrm{HC}$ specification in the inner ear (Lanford et al., 2000; Zine and deRibaupierre, 2002). By suppressing Atoh1 during development, Notch-mediated lateral inhibition appears to inhibit progenitor/precursor cells from acquiring the $\mathrm{HC}$ fate. By preventing progenitor/precursor cells from differentiating as $\mathrm{HCs}$, Notch activation essentially conserves these cells in the sensory epithelium, perhaps allowing mitotic or non-mitotic production of HCs (or SCs) later in development, perhaps even postnatally. This role for Notch is also seen in several other tissues (reviewed in Kageyama et al., 2005). For example, in the developing cerebral cortex, loss of HES1/5 leads to significant decreases in clonal growth of neural stem cells in culture (Ohtsuka etal., 2001).

Since Notch has several functions in the development of inner ear sensory epithelia, it is tempting to hypothesize that these functions are reiterated in the chicken $\mathrm{BP}$ during $\mathrm{HC}$ regeneration. Expression analyses in the mature chicken BP support this hypothesis (Stone and Rubel, 1999). In the quiescent (undamaged) chicken BP, SCs actively transcribe Notch1 and Serrate1, but no transcription of Delta 1 is seen in either HCs or SCs. A third Notch ligand, Serrate2, is expressed in developing HCs (Eddison et al., 2000) and may also be expressed in mature HCs. This general pattern of Notch-related gene expression is comparable to what is seen in the mature organ of Corti. By $3 d$ postGentamicin, Delta 1 transcripts become increased in dividing SCs and are later highly upregulated in daughter cells as they differentiate into HCs. Delta 1 levels are low in post-mitotic, regenerated SCs and expression of Delta 1 during transdifferentiation has not been explored. By 10d post-Gentamicin, Delta1 is highly downregulated. Changes in Notch1, Serrate1 and Serrate2 have not been extensively described after $\mathrm{HC}$ loss.

The precise roles for Notch in the quiescent and regenerating BP have not been functionally tested, although some hypotheses can be drawn based on these expression data (Fig. 3B). In the quiescent (undamaged) state, the Notch1 receptor in SCs may be activated by neighboring HCs via Serrate2 (or by SCs via Serrate1). This activation may maintain SC identity and/or SC quiescence, preventing SCs from converting into HCs. Shortly after Gentamicin treatment, Notch receptor or ligand function may be diminished, leading (in SCs) to decreased Notch activity, increased Atoh1 transcription and transdifferentiation toward the $\mathrm{HC}$ phenotype. Retention of Notch activation in some SCs could prevent them from transdifferentiating, conserving them for critical functions in the BP or for mitotic regeneration at a later time. In post-mitotic cells, Notch activation, presumably via Delta1, would also specify cell fate determination (Stone and Rubel, 1999). Alternatively, Notch activity may be low or absent in the quiescent BP and activation of Notch may occur only after HC damage. In this case, increased Notch activity may be required to respecify progenitor cells (SCs) toward a sensory fate, as occurs during early development. In any event, once the function of Notch signaling is elucidated in the quiescent and damaged chicken inner ear, it will be important to investigate the degree to which Notch signaling is active in the mature mammalian inner ear after damage and which roles Notch plays in regulating SC responses after $\mathrm{HC}$ damage. Notch activity may limit the regenerative response in mammals, by preventing spontaneous SC transdifferentiation after HCs are lost or damaged.

\section{Signals regulating SC division}

A few studies have examined signals that trigger SCs to leave mitotic quiescence and enter the cell cycle. Although most evidence has been collected for vestibular SCs (reviewed in Oesterle and Hume, 1999; see below), some well known intracellular signaling pathways have been implicated in triggering SC division in the chicken BP. Using cochlear duct organ cultures, Navaratnam et al. (1996) showed that activation of adenylate cyclase increases the number of SCs that divide after Gentamicin exposure and modulation of this signaling leads to decreased SC division. 
Using cultures of pure utricular epithelium, a study by Witte et al. (2000) implicates additional second messengers, including PI-3 kinase, TOR-kinase and MAP-kinase, in the signaling cascade leading to SC division. Which extracellular factors might alter these signaling pathways? Addition of basic FGF (bFGF) to cultured cochlear ducts leads to decreased SC division (Oesterle et al., 2000). Consistent with this, expression of FGF receptor3 is abundant in quiescent SCs of the BP and becomes highly decreased in areas where numerous SCs are dividing, suggesting that attenuated signaling through this receptor must occur before SC re-entry into the cell cycle (Bermingham-McDonogh et al., 2001). In the avian vestibular epithelium, in vitro experiments demonstrate SC proliferation is inhibited by bFGF (Oesterle et al., 2000), Retinoic Acid (Warchol, 2002), N cadherin (Warchol, 2006) and Dexamethasone (Warchol, 1999). In contrast, Insulin, Insulin-like Growth Factor 1, Transforming Growth Factor alpha and Tumor Necrosis Factor alpha have mitogenic effects on vestibular SCs, as does the extracellular matrix molecule, Fibronectin (Oesterle et al., 1997; Warchol, 2002). At this point, effects of the various signaling molecules just described remain to be tested in vivo. Further, localization of critical ligands and receptors is required. These observations suggest that multiple signaling pathways interact in a SC to regulate its cell cycle progression. Important future challenges are to link extracellular signals with specific intracellular pathways and to determine which pathways are dispensable versus critical to mitogenic regeneration in chickens. This information will guide additional experiments in mammals toward identifying whether SC division is stalled due to the absence of mitogenic signals or due to the activity of inhibitory signals in the mammalian sensory epithelium after HC loss.

\section{Differentiation in post-mitotic cells}

Very little information exists about how post-mitotic cells acquire features of SCs during regeneration of the chicken BP. However, differentiation of cells along the $\mathrm{HC}$ pathway has been studied to some extent (e.g., Stone and Rubel, 2000b; Roberson et al., 2004; Stone et al., 2004; Duncan et al., 2006; Cafaro et al., 2007). For example, some of the earliest known markers of HC differentiation are Myosins VI and VIla. In cochlear and vestibular end-organs of vertebrates, including chickens, immunolabeling has shown that Myosin VI and Myosin VIla protein is specifically localized to HCs (Hasson et al., 1997; Torchinsky et al., 1999; Mangiardi et al., 2004; Roberson et al., 2004; Duncan et al., 2006). MyosinVI protein has been documented as one of the earliest protein markers of $\mathrm{HC}$ differentiation in mouse embryos after Atoh 1 is upregulated (Montcouquiol and Kelley, 2003; Kelley, 2006). In the regenerating chick BP, HCs formed through either direct transdifferentiation or cell division show elevated levels of MyosinVI early during their differentiation. However, SCs undergoing direct transdifferentiation appear to take a relatively longer time to express MyosinVI compared to precursor cells formed by cell division. As discussed earlier, Atoh1 protein is detected in the nuclei of transdifferentiating SCs by $15 \mathrm{~h}$ post-Gentamicin (Cafaro et al., 2007). MyosinVI is detected in transdifferentiating SCs by 78h post-Gentamicin, or 63h later (Roberson et al., 2004). In contrast, newly post-mitotic cells exhibit detectable levels of MyosinVI by 108h post-Gentamicin (Roberson et al., 2004), which is only $36 \mathrm{~h}$ after the first proliferating cells complete mitosis (at 72h). There are at least two possible explanations for this delay in Myosin expression in HCs arising directly from SCs. First, it may take a considerable amount of time for quiescent SCs to downregulate SC-specific genes and to upregulate HC-specific genes. In contrast, newly formed post-mitotic precursor cells are probably in a very immature, labile state in terms of how readily new genes can be activated and accordingly, they are able to rapidly proceed down the $\mathrm{HC}$ differentiation pathway. A second explanation is that completion of cell fate specification and differentiation is delayed in early transdifferentiating cells because injured HCs remain in the epithelium, while in contrast, most injured $\mathrm{HCs}$ have been completely ejected by the time SC division is triggered. (The peak period of $\mathrm{HC}$ ejection occurs between $30 \mathrm{~h}$ and $42 \mathrm{~h}$ [Mangiardi et al., 2004], which overlaps with initial SC transdifferentiation but precedes the initiation of SC division.) This form of regulation would suggest that dying HCs control the progression of SCs through the two regeneration pathways.

\section{Controlling regeneration: balancing modes of regen- eration and re-establishing SC quiescence}

Sensory epithelia of the inner ear and lateral line neuromasts are highly specialized and their function depends upon the precise arrangement of HCs and SCs. Therefore, it is of utmost importance that the correct number and type of cells be reestablished during regeneration. Direct transdifferentiation poses a specific problem, because each time a new $\mathrm{HC}$ is formed using this mechanism, a SC is lost from the epithelium. Tight regulation of direct transdifferentiation is essential, because, at a ratio of only 2-4 SCs per HC (Goodyear and Richardson, 1997), excessive direct transdifferentiation would lead to SC depletion. Since direct transdifferentiation is initiated early, it is tempting to hypothesize that $\mathrm{SC}$ conversion into $\mathrm{HCs}$ has evolved as an early, rapid way to make new HCs if only a few are lost. However, if a large number of $\mathrm{HCs}$ die, then the cochlea must activate mitosis to maintain the integrity of the sensory epithelium. The selective differentiation of post-mitotic precursors into SCs would counteract SC depletion to direct transdifferentiation. SC divisions can generate either HCs or SCs (Raphael, 1992; Stone and Cotanche, 1994) and during early stages of SC proliferation, each mitotic event is equally likely to give rise to symmetrically differentiating pairs of daughter cells (2 SCs or $2 \mathrm{HCs}$ ) or an asymmetric pair ( $1 \mathrm{HC}$ and 1SC; Stone and Rubel, 2000b). However, specific temporospatial patterns of mitotic regeneration have not been characterized at different periods of regeneration, so it is not clear at this time whether mitotic regeneration is sufficient to compensate for direct transdifferentiation or if other mechanisms (e.g., cell death, cell rearrangement, or immigration of cells from outside the epithelium) are also involved.

Inhibition of SC activity in the BP is also highly important for establishing the correct number and type of new cells. Mechanisms for halting regenerative behavior in SCs have received considerably less attention than those initiating it and are therefore poorly understood. One attractive control that has been documented in other sensory epithelia is a negative feedback mechanism, whereby regenerated $\mathrm{HCs}$ and/or SCs inhibit nearby SCs from further division or transdifferentiation (e.g., see Bermingham-McDonogh et al., 2001). Negative feedback may 
indeed be active in the regenerating inner ear epithelium. It is clear, however, that if negative feedback for SC division were derived from regenerating $\mathrm{HCs}$, then the signaling $\mathrm{HCs}$ would be quite immature, because SC division becomes highly attenuated before well differentiated new HCs emerge in the epithelium. The peak of BrdU uptake during regeneration occurs at $72 \mathrm{~h}$ after a single Gentamicin injection and this begins to taper off by $96 \mathrm{~h}$ and is greatly reduced by $120 \mathrm{~h}$ (Bhave et al., 1995; Duncan et al., 2006). The first identifiable markers of $\mathrm{HC}$ differentiation in newly divided cells (Myosin VI and TUJ1) appear at 96-108h, just about the same time that BrdU labeling begins to decrease.

\section{Comparisons with mammals}

Mammalian inner ear SCs are similar to those in birds in that they share a common progenitor cell with HCs during development and they remain in close contact with $\mathrm{HCs}$ in maturity. Yet, SCs of the mammalian organ of Corti fail to show any regenerative response to $\mathrm{HC}$ loss, via either direct transdifferentiation or mitosis (e.g., see Forge etal., 1998). In contrast, there is evidence that considerable spontaneous regeneration of HCs does occur in the mammalian vestibular epithelium, most likely through direct transdifferentiation (Forge et al., 1998).

Several studies suggest that the capacity to regenerate HCs via either mitotic or non-mitotic avenues is lost from the mammalian organ of Corti over the course of post-embryonic maturation. For example, cultured SCs from the early post-natal organ of Corti show robust proliferation and a fraction of post-mitotic cells can differentiate into new HCs (Malgrange et al., 2002; Doetzlhofer et al., 2004; White et al., 2006), but this capacity is lost with time (White et al., 2006; Oshima et al., 2007). It is not clear if this developmental change reflects an intrinsic shift in SC properties or an absence of appropriate mitogenic signals in maturity. However, recent studies provide support for the former hypothesis. During embryogenesis, cells in the embryonic cochlear epithelium upregulate expression of the cyclin-dependent kinase inhibitor, p27kip1, around the time that terminal mitosis is beginning (Chen and Segil, 1999; Löwenheim et al., 1999). Levels of $\mathrm{p} 27^{\mathrm{kip} 1}$ protein remain robust in differentiated SCs in the mature organ of Corti, suggesting that p2 $7^{\mathrm{kip} 1}$ imposes strong inhibition on cell cycle progression in mature SCs and may prevent them from dividing in response to $\mathrm{HC}$ loss. Deletion of the $p 27^{k i p} 1$ gene supports this hypothesis, since knockout mice show extended periods of developmental progenitor cell division and supernumerary production of both $\mathrm{HCs}$ and SCs in vivo (Löwenheim et al., 1999; Chen and Segil, 1999) and increased rates of proliferation in vitro (White et al., 2006). Similar results are seen when the negative cell cycle regulator, $\mathrm{Rb}$, is deleted (Sage et al., 2005; Sage et al., 2006). Although loss of cell cycle inhibitors also results in increased apoptosis, these knockout experiments indicate that the inhibition of SC proliferation seems to be a major step in blocking $\mathrm{HC}$ regeneration in the mammalian cochlea. Similarly, SCs may lose the ability to directly convert into HCs over development. Kelley et al. (1995) showed that new HCs are generated in the mouse organ of Corti prior to E16 when existing HCs are ablated using a laser, but this capability is lost after E16. In postnatal rats, treatment with the otoxin, Amikacin, causes a large $\mathrm{HC}$ lesion and leads to the emergence of cells that resemble $\mathrm{HC}-\mathrm{SC}$ hybrids (Daudet et al., 1998). While these cells have been hypothesized to be SCs that have initiated direct transdifferentiation, they fail to differentiate many $\mathrm{HC}$ features. Together, these findings suggest that the ability of auditory SCs to undergo direct transdifferentiation is lost over development. Mature SCs may be too differentiated to undergo direct transdifferentiation, or there may be signaling mechanisms that prevent it. As we begin to understand more about how the SC to $\mathrm{HC}$ conversion is regulated in the avian $\mathrm{BP}$, we will be able to better dissect the degree to which SCs initiate direct transdifferentiation in the mammalian organ of Corti.

A few studies suggest that $\mathrm{HC}$ regeneration may occur in the vestibular epithelium of mature mammals. For example, Forge et al. (1998) performed careful morphologic analyses of vestibular epithelia in guinea pigs following ototoxic drug treatment at different time-points. Hair cells appeared to be completely lost from the striolar region one-to-two weeks after treatment. However, $\mathrm{HC}$ numbers were increased in this region by 2-4 weeks after treatment. Since little SC division occurs spontaneously after $\mathrm{HC}$ damage in the utricle of adult guinea pigs (Rubel et al., 1995), new HCs likely arose through direct transdifferentiation of SCs. This interpretation is supported by the finding that SC numbers decreased after recovery, which is predicted to occur if SCs had converted into HCs without mitotic replacement. In addition, studies of cultured vestibular end organs show that addition of serum or growth factors significantly upregulates SC division in the mature vestibular epithelium, in vitro (Warchol et al., 1993; Lambert, 1994; Yamashita and Oesterle, 1995; Hume et al., 2003) and in vivo (Kuntz and Oesterle, 1998). However, it remains to be clearly demonstrated if a significant number of postmitotic cells is able to differentiate into HCs.

\section{Summary and future directions}

Studies of non-mammalian vertebrates, birds in particular, have revealed several important features of the cellular and molecular processes associated with development and regeneration of sensory hair cells (HCs). Investigations of progressive morphological and molecular changes that occur in the damaged sensory epithelium have begun to pinpoint intracellular signaling pathways that may regulate $\mathrm{HC}$ apoptosis and trigger surrounding non-sensory, supporting cells (SCs) to become activated to leave quiescence and to de-differentiate toward a more primitive progenitor-like state. Additional candidate regulatory molecules, including diffusible factors and transcription factors, then direct SCs to undergo phenotypic conversion into $\mathrm{HCs}$ or to divide, forming progeny that differentiate into new HCs and SCs. Despite this progress in our understanding, considerable work remains to be done in defining critical signaling pathways involved in these stages of regeneration. In particular, signals that maintain SCs in quiescence in the undamaged state and/or retain stem-like progenitors during regeneration must be identified. Further, we must determine the degree to which SC behavior after $\mathrm{HC}$ damage is determined by intrinsic cellular changes versus locally released signals. These aspects of cellular regulation are highly relevant to determining why mammalian SCs generally remain in a quiescent state after $\mathrm{HC}$ loss.

Recent advances in techniques used to study non-mammalian $\mathrm{HC}$ regeneration promise to broaden our understanding of molecular signaling required to trigger SCs to generate new $\mathrm{HCs}$. For 
example, two recent studies (Hawkins et al., 2003; Hawkins et al., 2007) used genomic profiling to identify a large number of genes that are altered in the avian auditory and/or vestibular epithelium after $\mathrm{HC}$ damage. This characterization was accomplished with gene microchips, which define relative levels of tens of thousands of transcripts in a given tissue and allow one to compare levels of expression across tissue samples. Microchip analyses enable the identification of molecular markers and signaling pathways heretofore unknown to be relevant for $\mathrm{HC}$ regeneration. These studies have confirmed differential expression levels of some candidate genes using quantitative polymerase chain reaction and in situ hybridization, which provides additional assurance of the validity of the approach. Follow-up technologies must now be developed to enable investigators to accept or reject hypotheses regarding the role of specific candidate genes in $\mathrm{HC}$ regeneration. Two examples of these are gene knock-down and gene misexpression. Inhibition of gene function through knockdown can be accomplished with RNA interference or RNA antisense approaches. Gene misexpression can be accomplished through delivery of conditionally or constitutively active genes into cells of interest. To our knowledge, no studies involving genetic perturbation in the post-embryonic amphibian or avian inner ear have been performed. However, delivery of modified nucleic acids into the developing chicken otocyst has been accomplished using retrivirus (e.g., Fekete et al., 1998), electroporation (e.g., Daudet and Lewis, 2005) and antisense morpholinos (Gerlach-Bank et al., 2004). The challenge is now to bring these methods for gene transfection and transduction into tissues of the mature inner ear.

Another new area of study in the genetics of $\mathrm{HC}$ loss and regeneration has recently been developed in zebrafish, a classic model for genetics experiments. Hair cells of the lateral line neuromast are positioned along the external body wall of these fish. Neuromasts are therefore highly accessible to aminoglycosides and allow visual monitoring during $\mathrm{HC}$ damage and regeneration. Recent studies have investigated lateral line $\mathrm{HCs}$ and SCs after treatment with the aminoglycoside antibiotic, Neomycin (e.g., Williams and Holder, 2000; Harris et al., 2003). At this point, published studies have characterized only the basic morphologic events that occur. Nonetheless, these studies provide proof of concept that the behavior of lateral line HCs and SCs after aminoglycoside exposure is highly analogous to the inner ear of birds and amphibians. One group (E.W. Rubel, D. Raible et al.) are now conducting mutagenesis studies in zebrafish aimed at identifying genes that confer either protection or increased susceptibility of lateral line HCs to Neomycin, as well as genes that alter the regenerative process after Neomycin exposure. In addition, parallel studies are screening small molecule libraries to identify drugs that alter $\mathrm{HC}$ damage after Neomycin. It would be interesting to determine the degree to which blockade of $\mathrm{HC}$ loss at various stages of the process alters SC responses. This information could help to pinpoint which $\mathrm{HC}$ changes must occur in order for SCs to become activated and initiate $\mathrm{HC}$ regeneration.

In conclusion, since the discovery of $\mathrm{HC}$ regeneration in birds over 20 years ago, significant progress has been made in characterizing $\mathrm{HC}$ progenitors and their activities following $\mathrm{HC}$ loss in the inner ear of mature non-mammalian vertebrates. It is anticipated that future studies of molecular interactions governing $\mathrm{HC}$ development will continue to point the way for investigators interested in unraveling regulation of post-embryonic $\mathrm{HC}$ production. In addition, pioneering experimental approaches just described, as well as others, should help to identify new genes of interest and to reveal their function during $\mathrm{HC}$ regeneration.

\section{References}

ADAM J, MYAT A, LE ROUX I, EDDISON M, HENRIQUE D, ISH-HOROWICZ D, LEWIS J (1998) Cell fate choices and the expression of Notch, Delta and Serrate homologues in the chick inner ear: parallels with Drosophila sense-organ development. Development 125(23):4645-54.

ADLER J, LEE KJ, JESSELL TM, HATTEN ME (1996) New hair cells arise from supporting cell conversion in the acoustically damaged chick inner ear. Neurosci Lett. 205(1):17-20. Erratum in: Neurosci Lett 24;210(1):73.

ARTAVANIS-TSAKONAS S, SIMPSON P (1991) Choosing a cell fate: a view from the Notch locus. Trends Genet 7(11-12):403-8.

BAIRD RA, TORRES MA, SCHUFF NR (1993) Hair cell regeneration in the bullfrog vestibular otolith organs following aminoglycoside toxicity. Hear Res 65(12):164-74.

BAIRD RA, STEYGER PS, SCHUFF N (1996) Mitotic and nonmitotic hair cell regeneration in the bullfrog vestibular otolith organs. Ann N Y Acad Sci781:5970.

BAIRD RA, BURTON MD, FASHENA DS, NAEGER RA (2000) Hair cell recovery in mitotically blocked cultures of the bullfrog saccule. Proc Nat/ Acad Sci USA 97(22):11722-9.

BALAK KJ, CORWIN JT, JONES JE (1990) Regenerated hair cells can originate from supporting cell progeny: evidence from phototoxicity and laser ablation experiments in the lateral line system. JNeurosci10(8):2502-12.

BAKER NE, YU SY (1997) Proneural function of neurogenic genes in the developing Drosophila eye. Curr Bio/7(2):122-32.

BAKER NE, YU S, HAN D (1996) Evolution of proneural atonal expression during distinct regulatory phases in the developing Drosophila eye. Curr Bio/6(10):1290301.

BEITES CL, KAWAUCHI S, CROCKER CE, CALOF AL (2005) Identification and molecular regulation of neural stem cells in the olfactory epithelium. Exp Cell Resn306(2):309-16.

BEN-ARIE N, HASSAN BA, BERMINGHAM NA, MALICKI DM, ARMSTRONG D, MATZUK M, BELLEN HJ, ZOGHBI HY (2000) Functional conservation of atonal and Math1 in the CNS and PNS. Development 127(5):1039-48.

BERESFORD WA (1990) Direct transdifferentiation: can cells change their phenotype without dividing? Cell Differ Dev. 29(2):81-93.

BERMINGHAM NA, HASSAN BA, PRICE SD, VOLLRATH MA, BEN-ARIE N, EATOCK RA, BELLEN HJ, LYSAKOWSKI A, ZOGHBI HY (1999) Math1: an essential gene for the generation of inner ear hair cells. Science 284:18371841.

BERMINGHAM-MCDONOGH O, STONE JS, REH TA, RUBEL EW (2001) FGFR3 expression during development and regeneration of the chick inner ear sensory epithelia. Dev Bio/238:247-259.

BERMINGHAM-MCDONOGH O, RUBEL EW (2003) Hair cell regeneration: winging our way towards a sound future. Curr. Opin. Neurobiol. 13(1):119-26.

BHAVE SA, STONE JS, RUBEL EW, COLTRERA MD (1995) Cell cycle progression in Gentamicin-damaged avian cochleas. J Neurosci15(6):4618-28.

BOUCHIER-HAYES L, LARTIGUE L, NEWMEYER DD (2005) Free in PMC Mitochondria: pharmacological manipulation of cell death. $J$ Clin Invest 115(10):2640-7.

BROOKER R, HOZUMI K, LEWIS J (2006) Notch ligands with contrasting functions: Jagged1 and Delta1 in the mouse inner ear. Development 133(7):1277-86.

BROWN ST, MARTIN K, GROVES AK (2003) Molecular basis of inner ear induction. Curr Top Dev Bio/57:115-49.

CAFARO, J, LEE, GS, STONE, JS (2007) Atoh1 expression defines activated progenitors as well as differentiating hair cells during avian hair cell regeneration. Developmental Dynamics, 236:156-170.

CHARDIN S, ROMAND R (1997) Factors modulating supernumerary hair cell production in the postnatal rat cochlea in vitro. Int J Dev Neurosci15(4-5):497507. 
CHEN P, SEGIL N (1999) p27(Kip1) links cell proliferation to morphogenesis in the developing organ of Corti. Development 126(8):1581-90.

CHEN P, JOHNSON JE, ZOGHBI HY, SEGIL N (2002) The role of Math1 in inner ear development: Uncoupling the establishment of the sensory primordium from hair cell fate determination. Development 129(10):2495-505.

CHENG AG, CUNNINGHAM LL, RUBEL EWN(2003) Hair cell death in the avian basilar papilla: characterization of the in vitro model and Caspase activation. $J$ Assoc Res Otolaryngo/4(1):91-105.

CHITNIS A, KINTNER C (1996) Sensitivity of proneural genes to lateral inhibition affects the pattern of primary neurons in Xenopus embryos. Development 122(7):2295-301.

COLE LK, LE ROUX I, NUNES F, LAUFER E, LEWIS J, WU DK (2000) Sensory organ generation in the chicken inner ear: contributions of bone morphogenetic protein 4, serrate1 and lunatic fringe. J Comp Neuro/424(3):509-20.

CORWIN JT (1981) Postembryonic production and aging in inner ear hair cells in sharks. J Comp Neuro/201(4):541-53.

CORWIN JT (1985) Perpetual production of hair cells and maturational changes in hair cell ultrastructure accompany postembryonic growth in an amphibian ear. Proc Natl Acad Sci USA 82(11):3911-5.

CORWIN JT, COTANCHE DA (1988) Regeneration of sensory hair cells after acoustic trauma. Science 240: 1772-1774.

COTANCHE DA (1987a) Regeneration of hair cell stereociliary bundles in the chick cochlea following severe acoustic trauma. Hear Res 30:181-195.

COTANCHE DA (1987b) Regeneration of the tectorial membrane in the chick cochlea following severe acoustic trauma. Hear Res 30(2-3):197-206.

COTANCHE DA (1999) Structural recovery from sound and aminoglycoside damage in the avian cochlea. Audiol Neurooto/4(6):271-85.

COTANCHE DA, HENSON MM, HENSON OW JR (1992) Contractile proteins in the hyaline cells of the chicken cochlea. J Comp Neuro/324(3):353-64.

COTANCHE DA, MESSANA EP, OFSIE MS (1995) Migration of hyaline cells into the chick basilar papilla during severe noise damage. HearRes91(1-2):148-59.

COUTINHO, P., GOODYEAR, R., LEGAN, P.K., RICHARDSON, G.P. 1999. Chick a-tectorin: molecular cloning and expression during embryogenesis. Hear. Res. $130,62-74$

CRUZ RM, LAMBERT PR, RUBEL EW (1987) Light microscopic evidence of hair cell regeneration after Gentamicin toxicity in chick cochlea. Arch Otolaryngol Head Neck Surg 113(10):1058-62.

CUNNINGHAM LL, CHENG AG, RUBEL EW (2002) Caspase activation in hair cells of the mouse utricle exposed to Neomycin. JNeurosci22(19):8532-40.

CRYNS, V, YUAN, J (1998) Proteases to die for [published erratum appears in genes dev 1999 feb 1;13(3):371]. Genes Dev, 12(11): 1551-1570.

DAI CF, MANGIARDI D, COTANCHE DA, STEYGER PS (2006) Uptake of fluorescent Gentamicin by vertebrate sensory cells in vivo. Hear Res 213(1-2):64-78. Epub 2006 Feb 8.

DAUDET N, VAGO P, RIPOLL C, HUMBERT G, PUJOL R, LENOIR M (1998) Characterization of atypical cells in the juvenile rat organ of corti after aminoglycoside ototoxicity. J Comp Neuro/401(2):145-62.

DAUDET N, LEWIS J (2005) Two contrasting roles for Notch activity in chick inner ear development: specification of prosensory patches and lateral inhibition of hair-cell differentiation. Development 132(3):541-51.

DAUDET N, ARIZA-MCNAUGHTON L, LEWIS J (2007) Notch signalling is needed to maintain, but not to initiate, the formation of prosensory patches in the chick inner ear. Development 134(12):2369-78.

DOETZLHOFER A, WHITE PM, JOHNSON JE, SEGIL N, GROVES AK (2004) In vitro growth and differentiation of mammalian sensory hair cell progenitors for EGF and periotic mesenchyme. Dev Bio/272:432-447.

DUNCAN LJ, MANGIARDI DA, MATSUI JI, ANDERSON JK, MCLAUGHLINWILLIAMSON K, COTANCHE DA. (2006) Differential expression of unconventional myosins in apoptotic and regenerating chick hair cells confirms two regeneration mechanisms. J Comp Neuro/499(5):691-701.

DYER MA, LIVESEY FJ, CEPKO CL, OLIVER G (2003) Prox1 function controls progenitor cell proliferation and horizontal cell genesis in the mammalian retina. Nat Genet 34(1):53-8.

EARNSHAW, W. C., MARTINS, L. M., \& KAUFMANN, S. H. (1999). Mammalian
Caspases: Structure, activation, substrates and functions during apoptosis. Annu. Rev. Biochem., 68, 383-424.

EDDISON M, LE ROUX I, LEWIS J (2000) Notch signaling in the development of the inner ear: lessons from Drosophila. Proc Nat/ Acad Sci USA 97(22):116929.

EPSTEIN JE, COTANCHE DA (1995) Secretion of a new basal layer of tectorial membrane following Gentamicin-induced hair cell loss. Hear Res 90(1-2):3143.

FEKETE DM, WU DK (2002) Revisiting cell fate specification in the inner ear. Curr Opin Neurobiol12(1):35-42

FEKETE DM, MUTHUKUMAR S, KARAGOGEOS D (1998) Hair cells and supporting cells share a common progenitor in the avian inner ear. JNeurosch 8(19):781121.

FORGE A, LI L, NEVILL G (1998) Hair cell recovery in the vestibular sensory epithelia of mature guinea pigs. J. Comp. Neurol. 397(1):69-88.

FORGE A, LI L, CORWIN JT, NEVILL G (1993) Ultrastructural evidence for hair cell regeneration in the mammalian inner ear. Science 259(5101):1616-9.

FORGE A, BECKER D, CASALOTTI S, EDWARDS J, MARZIANO N, NEVILL G (2003) Gap junctions in the inner ear: comparison of distribution patterns in different vertebrates and assessement of connexin composition in mammals. $J$ Comp Neuro/467(2):207-31.

GERLACH-BANK LM, CLEVELAND AR, BARALD KF (2004) DAN directs endolymphatic sac and duct outgrowth in the avian inner ear. Dev Dyn 229(2):219-30.

GOODYEAR R, RICHARDSON G (1997) Pattern formation in the basilar papilla: evidence for cell rearrangement. J Neurosci 17(16):6289-301.

GOODYEAR R, KILLICK R, LEGAN PK, RICHARDSON GP (1996) Distribution of beta-tectorin mRNA in the early posthatch and developing avian inner ear. Hear Res 96(1-2):167-78.

GOULD E (2007) How widespread is adult neurogenesis in mammals? Nat Rev Neurosci 8(6):481-8.

GOWAN K, HELMS AW, HUNSAKER TL, COLLISSON T, EBERT PJ, ODOM R, JOHNSON JE (2001) Crossinhibitory activities of Ngn1 and Math1 allow specification of distinct dorsal interneurons. Neuron 31(2):219-32.

HADDON C, JIANG YJ, SMITHERS L, LEWIS J (1998) Delta-Notch signalling and the patterning of sensory cell differentiation in the zebrafish ear: evidence from the mind bomb mutant. Development125(23):4637-44.

HARRIS JA, CHENG AG, CUNNINGHAM LL, MACDONALD G, RAIBLE DW, RUBEL EW (2003) Neomycin-induced hair cell death and rapid regeneration in the lateral line of zebrafish (Danio rerio). J Assoc Res Otolaryngo/4(2):219-3

HASHINO E, TANAKA Y, SOKABE M (1991) Hair cell damage and recovery following chronic application of kanamycin in the chick cochlea. Hear Res 52(2):356-68.

HASHINO E, SALVI R“(1993) Changing patterns of DNA replication in the noisedamaged chick cochlea. J Cel/ Science 105:23-31.

HASSON T, GILLESPIE PG, GARCIA JA, MACDONALD RB, ZHAO Y, YEE AG, MOOSEKER MS, COREY DP (1997) Unconventional myosins in inner-ear sensory epithelia. J Cel/ Bio/137(6):1287-307.

HAWKINS RD, BASHIARDES S, HELMS CA, HU L, SACCONE NL, WARCHOL ME, LOVETT M (2003) Gene expression differences in quiescent versus regenerating hair cells of avian sensory epithelia: implications for human hearing and balance disorders. Hum Mol Genet12(11):1261-72.

HAWKINS RD, BASHIARDES S, POWDER KE, SAJAN SA, BHONAGIRI V, ALVARADO DM, SPECK J, WARCHOL ME, LOVETT M (2007) Large scale gene expression profiles of regenerating inner ear sensory epithelia. PLOSONE 13;2:e525.

HEITZLER P, BOUROUIS M, RUEL L, CARTERET C, SIMPSON P (1996) Genes of the Enhancer of split and achaete-scute complexes are required for a regulatory loop between Notch and Delta during lateral signalling in Drosophila. Development 122(1):161-71.

HELMS AW, ABNEY AL, BEN-ARIE N, ZOGHBI HY, JOHNSON JE (2000) Autoregulation and multiple enhancers control Math1 expression in the developing nervous system. Development 127(6):1185-96.

HIROKAWA N (1978) The ultrastructure of the basilar papilla of the chick. J Comp Neuro/181(2):361-74.

HIROSE K, WESTRUM LE, CUNNINGHAM DE, RUBEL EW (2004) Electron 
microscopy of degenerative changes in the chick basilar papilla after Gentamicin exposure. J Comp Neuro/470(2):164-80.

HUME CR, KIRKEGAARD M, OESTERLE EC (2003) ErbB expression: The mouse inner ear and maturation of the mitogenic response to heregulin. JAssoc Res Otolaryngo/4:422-443.

IZUMIKAWA M, MINODA R, KAWAMOTO K, ABRASHKIN KA, SWIDERSKI DL, DOLAN DF, BROUGH DE, RAPHAEL Y (2005(Auditory hair cell replacement and hearing improvement by Atoh1 gene therapy in deaf mammals. Nat Med $11(3): 271-6$.

JANAS JD, COTANCHE DA, RUBEL EW (1995) Avian cochlear hair cell regeneration: stereological analyses of damage and recovery from a single high dose of Gentamicin. Hear Res 92(1-2):17-29.

JARMAN AP, GRAU Y, JAN LY, JAN YN (1993) atonal is a proneural gene that directs chordotonal organ formation in the Drosophila peripheral nervous system. Cel/73(7):1307-21.

JØRGENSEN, J, MATHIESSEN, C (1988) The avian inner ear. Continuous production of hair cells in vestibular sensory organs, but not in the auditory papilla. Naturwissenschaften. 75(6):319-20.

JONES JE, CORWIN JT (1993) Replacement of lateral line sensory organs during tail regeneration in salamanders: identification of progenitor cells and analysis of leukocyte activity. J Neurosci13(3):1022-34.

JONES JE, CORWIN JT (1996) Regeneration of sensory cells after laser ablation in the lateral line system: hair cell lineage and macrophage behavior revealed by time-lapse video microscopy. J Neurosci 16(2):649-62.

KAGEYAMA R, SASAIY, AKAZAWA C, ISHIBASHI M, TAKEBAYASHIK, SHIMIZU C, TOMITA K, NAKANISHI S (1995) Regulation of mammalian neural development by helix-loop-helix transcription factors. Crit Rev Neurobio/9(2-3):177-88.

KAGEYAMA R, OHTSUKA T, HATAKEYAMA J, OHSAWA R (2005) Roles of bHLH genes in neural stem cell differentiation. Exp Cell Res. 306(2):343-8

KATAYAMA A, CORWIN JT (1989) Cell production in the chicken cochlea. J Comp Neuro/281:129-135.

KAWAMOTO K, ISHIMOTO S-I, MINODA R, BROUGH DE, RAPHAEL Y (2003) Math1 gene transfer generates new cochlear hair cells in mature guinea pigs in vivo. JNeurosci23(11):4395-4400.

KEDERSHA N, CHO MR, LI W, YACONO PW, CHEN S, GILKS N, GOLAN DE, ANDERSON P (2000) Dynamic shuttling of TIA-1 accompanies the recruitment of mRNA to mammalian stress granules. J Cel/ Bio/151(6):1257-68.

KELLEY MW, TALREJA DR, CORWIN JT (1995) Replacement of hair cells after laser microbeam irradiation in cultured organs of corti from embryonic and neonatal mice. JNeurosci15(4):3013-26.

KELLEY MW (2006) Regulation of cell fate in the sensory epithelia of the inner ear. Nat Rev Neurosci 7(11):837-49. Review. Erratum in: Nat Rev Neurosci. 2007 $\operatorname{Mar} ; 8(3): 239$

KERR, J, WILLIE, A AND CURRIE, A (1972). Apoptosis: A basic biological phenomenon with wide-ranging implications in tissue kinetics. British Journal of Cancer, 26: 239-257.

KIERNAN AE, AHITUV N, FUCHS H, BALLING R, AVRAHAM KB, STEEL KP HRABE DE ANGELIS M (2001) The Notch ligand Jagged1 is required for inner ear sensory development. Proc Natl Acad Sci USA 98:3873-3878.

KIERNAN AE, CORDES R, KOPAN R, GOSSLER A, GRIDLEY T (2005) The Notch ligands DLL1 and JAG2 act synergistically to regulate hair cell development in mammalian inner ear. Development 132(19):4353-62.

KIERNAN AE, XU J, GRIDLEY T (2006) The Notch ligand JAG1 is required for sensory progenitor development in the mammalian inner ear. PLOS Genet 2(1):e4.

KIL J, WARCHOL ME, CORWIN JT (1997) Cell death, cell proliferation and estimates of hair cell life spans in the vestibular organs of chicks. Hear Res 114:117-126

KILLICK R, LEGAN PK, MALENCZAK C, RICHARDSON GP (1995) Molecula cloning of chick beta-tectorin, an extracellular matrix molecule of the inner ear. $J$ Cell Biol129(2):535-47.

KRUGER RP, GOODYEAR RJ, LEGAN PK, WARCHOL ME, RAPHAEL Y, COTANCHE DA, RICHARDSON GP (1999) The supporting-cell antigen: a receptor-like protein tyrosine phosphatase expressed in the sensory epithelia of the avian inner ear. JNeurosci19(12):4815-27.
KUNTZ AL, OESTERLE EC (1998) Transforming growth factor alpha with insulin stimulate cell proliferation in vivo in adult rat vestibular sensory epithelium. $J$ Comp Neuro/399:413-423.

LAMBERT PR (1994) Inner ear hair cell regeneration in a mammal: identification of a triggering factor. Laryngoscope 104:701-718.

LANFORD PJ, LAN Y, JIANG R, LINDSELL C, WEINMASTER G, GRIDLEY T, KELLEY MW (1999) Notch signalling pathway mediates hair cell development in mammalian cochlea. Nat Genet 21(3):289-92.

LANFORD PJ, SHAILAM R, NORTON CR, GRIDLEY T, KELLEY MW (2000) Expression of Math1 and HES5 in the cochleae of wildtype and Jag2 mutant mice. J Assoc Res Otolaryngo/ 1(2):161-71.

LAVRIK IN, GOLKS A, KRAMMER PH (2005) Caspases: pharmalogical manipulation of cell death. J Clin Invest 115:2665-2672.

LEE YS, LIU F, SEGIL N (2006) A morphogenetic wave of p27Kip1 transcription directs cell cycle exit during organ of Corti development. Development133(15):2817-26

LEWIS, J (1996) Neurogenic genes and vertebrate neurogenesis. Curr. Opin. Neurobiol. 6:3-10.

LÖWENHEIM H, FURNESS, DN, KIL J., ZINN C., GÜLTIG, K., FERO ML., FROST D., GUMMER AW, ROBERTS JM, RUBEL EW, HACKNEY CM, ZENNERHP (1999) Gene disruption of p27(Kip1) allows cell proliferation in the postnatal and adult organ of corti. Proc Nat Acad Sci USA 96: 4084-4088.

LUMPKIN EA, COLLISSON T, PARABP, OMER-ABDALLA A, HAEBERLA H, CHEN P, DOETZLHOFER A, WHITE P, GROVES A, SEGIL N, JOHNSON JE (2003) Math1-driven GFP expression in the developing nervous system of transgenic mice. Gene Expr Patterns 3(4):389-95.

MALGRANGE B, BELACHEW S, THIRY M, NGUYEN L, ROGISTER B, ALVAREZ ML, RIGO JM, VAN DE WATER TR, MOONEN G, LEFEBVRE PP (2002) Proliferative generation of mammalian auditory hair cells in culture. Mech Dev 112(1-2):79-88

MANGIARDIDA, MCLAUGHLIN-WILLIAMSONK, MAY KE, MESSANAEP, MOUNTAIN DC, COTANCHE DA (2004) Progression of hair cell ejection and molecular markers of apoptosis in the avian cochlea following Gentamicin treatment. $J$ Comp Neuro/475(1):1-18.

MATEI V, PAULEY S, KAING S, ROWITCH D, BEISEL KW, MORRIS K, FENG F, JONES K, LEE J, FRITZSCH B (2005) Smaller inner ear sensory epithelia in Neurog 1 null mice are related to earlier hair cell cycle exit. Dev Dyn.234(3):63350.

MATSUI JI, OGILVIE JM, WARCHOL ME (2002) Inhibition of Caspases prevents ototoxic and ongoing hair cell death. JNeurosci22(4):1218-27.

MATSUI JI, HAQUE A, HUSS D, MESSANA EP, ALOSI JA, ROBERSON DW, COTANCHE DA, DICKMAN JD, WARCHOL ME (2003) Caspase inhibitors promote vestibular hair cell survival and function after aminoglycoside treatment in vivo. J Neurosci23(14):6111-22.

MATSUI JI, COTANCHE DA (2004) Sensory hair cell death and regeneration: two halves of the same equation. Curr Opin Otolaryngol HeadNeck Surg 12(5):41825.

MCDONALD ES, WINDEBANK AJ (2000). Mechanisms of neurotoxic injury and cell death. Clin Neurobehav Tox 18(3):525-540.

MILLIMAKI BB, SWEET EM, DHASON MS, RILEY BB (2007) Zebrafish atoh1 genes: classic proneural activity in the inner ear and regulation by Fgf and Notch. Development 134(2):295-305.

MIURA H, KUSAKABE Y, HARADA S (2006) Cell lineage and differentiation in taste buds. Arch Histol Cyto/69(4):209-25.

MONTCOUQUIOL M, CORWIN JT (2001) Brief treatments with forskolin enhance s-phase entry in balance epithelia from the ears of rats. JNeurosci21(3):97482.

MONTCOUQUIOL M, KELLEY MW (2003) Planar and vertical signals control cellular differentiation and patterning in the mammalian cochlea. $J$ Neurosci 23(28):9469-78.

MOREST DK, COTANCHE DA (2004) Regeneration of the inner ear as a model of neural plasticity. J Neurosci Res 78(4):455-60.

MORRISON A, HODGETTS C, GOSSLER A, HRABE DE ANGELIS M, LEWIS J (1999) Expression of Delta1 and Serrate1 (Jagged1) in the mouse inner ear. Mech Dev84(1-2):169-72. 
MUSKAVITCH MA (1994) Delta-notch signaling and Drosophila cell fate choice. Dev BiO/166: 415-30.

NATHANSON MA (1986) Transdifferentiation of skeletal muscle into cartilage: transformation or differentiation? Curr Top Dev Biol. 20:39-62.

NAVARATNAM DS, SU HS, SCOTT SP, OBERHOLTZER JC (1996) Proliferation in the auditory receptor epithelium mediated by a cyclic AMP-dependent signaling pathway. Nat Med2(10):1136-9.

NEVES J, KAMAID A, ALSINA B, GIRALDEZ F (2007) Differential expression of Sox2 and Sox 3 in neuronal and sensory progenitors of the developing inner ear of the chick. J Comp Neurol. 503(4):487-500

NICKEL, R., BECKER, D., \& FORGE, A. (2006). Molecular and functional characterization of gap junctions in the avian inner ear. J. Neurosci, 26, 6190-6199.

NIWA N, HIROMI Y, OKABE M (2004) A conserved developmental program for sensory organ formation in Drosophila melanogaster. Nat Genet36(3):293-7.

OESTERLE EC, RUBEL EW (1993) Postnatal production of supporting cells in the chick cochlea. Hear Res 66:213-24.

OESTERLE EC, HUME CR (1999) Growth factor regulation of the cell cycle in developing and mature inner ear sensory epithelia. J Neurocytol 28(1011):877-87.

OESTERLE EC, TSUE TT, RUBEL EW (1997) Induction of cell proliferation in avian inner ear sensory epithelia by insulin-like growth factor-l and insulin. $J$ Comp Neuro/380(2):262-74.

OESTERLE EC, BHAVE SA, COLTRERA MD (2000) Basic fibroblast growth factor inhibits cell proliferation in cultured avian inner ear sensory epithelia. J Comp Neuro/424(2):307-26.

OESTERLE EC, CUNNINGHAM DE, WESTRUM LE AND RUBEL EW (2003) Ultrastructural analysis of $(3 \mathrm{H})$ thymidine-labeled cells in the rat utricular macula. J Comp Neuro/463:177-195.

OSHIMA K, GRIMM CM, CORRALES CE, SENN P, MARTINEZ MONEDERO R, GELEOC GS, EDGE A, HOLT JR, HELLER S (2007) Differential distribution of stem cells in the auditory and vestibular organs of the inner ear. J Assoc Res Otolaryngo/8(1):18-31.

OGATA Y, SLEPECKY NB, TAKAHASHI M (1999) Study of the gerbil utricular macula following treatment with Gentamicin, by use of bromodeoxyuridine and calmodulin immunohistochemical labelling. Hear Res 133:53-60.

OHTSUKA T, SAKAMOTO M, GUILLEMOT F, KAGEYAMA R (2001) Roles of the basic helix-loop-helix genes Hes1 and Hes5 in expansion of neural stem cells of the developing brain. J Biol Chem 276(32):30467-74.

OPAS M, DZIAK E (1998) Direct transdifferentiation in the vertebrate retina. Int $J$ Dev Biol. 42(2):199-206.

POPPER AN, HOXTER B (1984) Growth of a fish ear: 1. Quantitative analysis of hair cell and ganglion cell proliferation. Hear Res 15(2):133-42.

PRESSON JC, LANFORD PJ, POPPER AN (1996) Hair cell precursors are ultrastructurally indistinguishable from mature support cells in the ear of a postembryonic fish. Hear Res. 100(1-2):10-20.

PUJADES C, KAMAID A, ALSINA B, GIRALDEZF (2006) BMP-signaling regulates the generation of hair-cells. Dev Bio/292(1):55-67.

RAPHAEL Y (1992) Evidence for supporting cell mitosis in response to acoustic trauma in the avian inner ear. J Neurocyto/21:663-671.

REDDY GV, RODRIGUES V (1999) Sibling cell fate in the Drosophila adult external sense organ lineage is specified by prospero function, which is regulated by Numb and Notch. Development 126(10):2083-92.

RILEY BB, CHIANG M, FARMER L, HECK R (1999) The deltaA gene of zebrafish mediates lateral inhibition of hair cells in the inner ear and is regulated by pax2.1. Development 126(24):5669-78.

ROBERSON DW, RUBEL EW (1994) Cell division in the gerbil cochlea after acoustic trauma. Am J Oto/15:28-34.

ROBERSON DF, WEISLEDER P, BOHRER PS, RUBEL EW(1992) Ongoing production of sensory cells in the vestibular epithelium of the chick. Hear Res 57(2):166-74.

ROBERSON DW, KREIG CS, RUBEL EW (1996) Light microscopic evidence that direct transdifferentiation gives rise to new hair cells in regenerating avian auditory epithelium. Aud Neurosci2:195-205.

ROBERSON DW, ALOSI JA, COTANCHE DA (2004) Direct transdifferentiation gives rise to the earliest new hair cells in regenerating avian auditory epithelium. $J$ Neurosci Res 78(4):461-71.

RUBEL EW, DEW LA, ROBERSON DW (1995) Mammalian vestibular hair cell regeneration [letter; comment]. Science 267:701-7.

RUBEN RJ (1967) Development of the inner ear of the mouse. A radioautographic study of terminal mitosis. Acta Otolaryngol Suppl. 220:1-44.

RYALS BM, RUBEL EW (1988) Hair cell regeneration after acoustic trauma in adult Coturnix quail. Science 240:1774-1776.

SAGE C, HUANG M, KARIMI K, GUTIERREZ G, VOLLRATH MA, ZHANG DS, GARCIA-ANOVEROS J, HINDS PW, CORWIN JT, COREY DP, CHEN ZY (2005) Proliferation of functional hair cells in vivo in the absence of the retinoblastoma protein. Science 307(5712):1114-8.

SAGE C, HUANG M, VOLLRATH MA, BROWN MC, HINDS PW, COREY DP, VETTER DE, CHEN ZY (2006) Essential role of retinoblastoma protein in mammalian hair cell development and hearing. Proc Natl Acad Sci USA,103(19):7345-50.

SELKOE D, KOPAN R. 2003) Notch and Presenilin: regulated intramembrane proteolysis links development and degeneration. Annu Rev Neurosci. 26:56597.

SHAILAM R, LANFORD PJ, DOLINSKY CM, NORTON CR, GRIDLEY T, KELLEY MW (1999) Expression of proneural and neurogenic genes in the embryonic mammalian vestibular system. J Neurocyto/28(10-11):809-19.

SHOU J, ZHENG JL, GAO WQ (2003) Robust generation of new hair cells in the mature mammalian inner ear by adenoviral expression of Hath1. Mol Cell Neurosci 23(2):169-79.

SMOLDERS JW (1999) Functional recovery in the avian ear after hair cell regeneration. Audio/ Neurooto/4(6):286-302.

SOBKOWICZ HM, AUGUST BK, SLAPNICK SM (1997) Cellular interactions as a response to injury in the organ of Corti in culture. Int J Dev Neurosci15:463-485.

STANKOVIC, K., RIO, C., XIA, A., SUGAWARA, M., ADAMS, J., LIBERMAN, M., ET AL. (2004). Survival of adult spiral ganglion neurons requires erbb receptor signaling in the inner ear. JNeurosci24, 8651-8661.

STONE, L (1933) The development of lateral line sense organs in amphibians observed in living and vital-stained preparations. J Comp Neuro/57:507-540.

STONE, L (1937) Further experimental studies of the development of lateral-line sense organs in the amphibians observed in living preparations. J Comp Neurol 68:83-115.

STONE JS, COTANCHE DA (1994) Identification of the timing of S phase and the patterns of cell proliferation during hair cell regeneration in the chick cochlea. $J$ Comp Neuro/341:50-67.

STONE JS, RUBEL EW (1999) Delta1 expression during avian hair cell regeneration. Development 126(5):961-73.

STONE JS, RUBEL EW (2000a) Cellular studies of auditory hair cell regeneration in birds. Proc Natl Acad Sci USA 97(22):11714-21.

STONE JS, RUBEL EW (2000b) Temporal, spatial and morphologic features of hair cell regeneration in the avian basilar papilla. J Comp Neuro/417(1):1-16.

STONE JS, LEANÕ SG, BAKER LP, RUBEL, EW (1996) Hair cell differentiation in chick cochlear epithelium after aminoglycoside toxicity: in vivo and in vitro observations. J Neurosci 16:6157-74.

STONE JS, CHOI YS, WOOLLEY SM, YAMASHITA H, RUBEL EW (1999) Progenitor cell cycling during hair cell regeneration in the vestibular and auditory epithelia of the chick. J Neurocyto/28(10-11):863-76.

STONE JS, SHANG JL, TOMAREV S (2003) Expression of Prox1 defines regions of the avian otocyst that give rise to sensory or neural cells. J Comp Neurol 460(4):487-502.

STONE JS, SHANG JL, TOMAREV S (2004) cProx1 immunoreactivity distinguishes progenitor cells and predicts hair cell fate during avian hair cell regeneration. Dev Dyn 230(4):597-614.

SUGAHARA, K, RUBEL, EW, CUNNINGHAM, LL (2006) NK signaling in Neomycin-induced vestibular hair cell death. Hear Res 221(1-2):128-35.

TAKASAKA T, SMITH CA (1971) The structure and innervation of the pigeon's basilar papilla. J Ultrastruct Res 35(1):20-65.

TAUPIN JL, TIAN Q, KEDERSHA N, ROBERTSON M, ANDERSON P (1995) The rna-binding protein tiar is translocated from the nucleus to the cytoplasm during 
fas-mediated apoptotic cell death. Proc Nat/ Acad Sci USA, 92(5), 1629-1633.

TAYLOR RR, FORGE A (2005) Hair cell regeneration in sensory epithelia from the inner ear of a urodele amphibian. J Comp Neurol. 484(1):105-20.

THORNBERRY, N. A. AND LAZEBNIK, Y (1998) Caspases: Enemies Within. Science 281:1312-1316.

TORCHINSKY C, MESSANA EP, ARSURA M, COTANCHE DA (1999) Regulation of p27Kip1 during Gentamicin mediated hair cell death. JNeurocytol. 1999 OctNov;28(10-11):913-24.

TSAI H, HARDISTY RE, RHODES C, KIERNAN AE, ROBY P, TYMOWSKALALANNE Z, MBURU P, RASTAN S, HUNTER AJ, BROWN SD, STEEL KP (2001) The mouse slalom mutant demonstrates a role for Jagged1 in neuroepithelial patterning in the organ of Corti. Hum Mol Genet 10:507-512.

TSUE TT, WATLING DL, WEISLEDER P, COLTRERA MD, RUBEL EW (1994) Identification of hair cell progenitors and intermitotic migration of their nuclei in the normal and regenerating avian inner ear. JNeurosci 14(1):140-52.

WANGEMANN P (2002) $\mathrm{K}(+)$ cycling and its regulation in the cochlea and the vestibular labyrinth. Audiol Neurooto/7(4):199-205.

WARCHOL ME (1999) Immune cytokines and dexamethasone influence sensory regeneration in the avian vestibular periphery. J Neurocyto/28:889-900.

WARCHOL ME (2002) Cell density and N-cadherin interactions regulate cell proliferation in the sensory epithelia of the inner ear. JNeurosci22(7):2607-16.

WARCHOL ME (2006) Characterization of supporting cell phenotype in the avian inner ear: Implications for sensory regeneration. Hear Res 227(1-2):11-8.

WARCHOL ME, CORWIN JT (1996) Regenerative proliferation in organ cultures of the avian cochlea: identification of the initial progenitors and determination of the latency of the proliferative response. J Neurosci 16:5466-77.

WARCHOL ME, SPECK JD“(2007) Expression of GATA3 and tenascin in the avian vestibular maculae: normative patterns and changes during sensory regeneration. J Comp Neuro/500(4):646-57.

WARCHOL ME, LAMBERT PR, GOLDSTEIN BJ, FORGE A, CORWIN JT (1993) Regenerative proliferation in inner ear sensory epithelia from adult guinea pigs and humans. Science 259:1619-22.

WEISLEDER P, RUBEL EW (1993) Hair cell regeneration after Streptomycin toxicity in the avian vestibular epithelium. J Comp Neuro/331(1):97-110.

WHITE PM, DOETZLHOFER A, LEE YS, GROVES AK, SEGIL (2006) Mammalian cochlear supporting cells can divide and trans-differentiate into hair cells. Nature 441(7096):984-7.

WIGLE JT, OLIVER G (1999) Prox1 function is required for the development of the murine lymphatic system. Ce//98(6):769-78.

WILLIAMS JA, HOLDER N (2000) Cell turnover in neuromasts of zebrafish larvae. Hear Res 143(1-2):171-81.

WITTE MC, MONTCOUQUIOL M, CORWIN JT (2000) Regeneration in avian hair cell epithelia: identification of intracellular signals required for S-phase entry. Eur J Neurosci14(5):829-38.

WOODS C, MONTCOUQUIOL M, KELLEY MW (2004) Math1 regulates development of the sensory epithelium in the mammalian cochlea. Nat Neurosci 1-9.

WYLLIE AH (1980) Glucocorticoid-induced thymocyte apoptosis is associated with endogenous endonuclease activation. Nature 284(5756):555-6.

YAMAMOTO N, TANIGAKI K, TSUJI M, YABE D, ITO J, HONJO T (2006) Inhibition of Notch/RBP-J signaling induces hair cell formation in neonate mouse cochleas. J Mol Med84(1):37-45.

YAMASHITA H, OESTERLE EC (1995) Induction of cell proliferation in mammalian inner ear sensory epithelia by transforming growth factor-alpha and epidermal growth factor. Proc Natl Acad Sci USA 92(8): 3152-3155.

YAN HY, SAIDEL WM, CHANG JS, PRESSON JC, POPPER AN (1991) Sensory hair cells of a fish ear: evidence of multiple types based on ototoxicity sensitivity. Proc Biol Sci245(1313):133-8.

ZHANG N, MARTIN GV, KELLEY MW, GRIDLEY T (2000) A mutation in the Lunatic fringe gene suppresses the effects of a Jagged2 mutation on inner hair cell development in the cochlea. Curr Biol. 10(11):659-62.

ZHENG JL, KELLER G, GAO WQ (1999) Immunocytochemical and morphological evidence for intracellular self-repair as an important contributor to mammalian hair cell recovery. JNeurosci 19(6):2161-70.

ZHENG JL AND GAO W-Q (2000) Overexpression of Math1 induces robust production of extra hair cells in postnatal rat inner ears. NatNeurosci3:580-586.

ZHENG JL, SHOU J, GUILLEMOT F, KAGEYAMA R, GAO WQ (2000) Hes1 is a negative regulator of inner ear hair cell differentiation. Development. 2000 (21):4551-60

ZINE A, DE RIBAUPIERRE F (2002) Notch/Notch ligands and Math1 expression patterns in the organ of Corti of wild-type and Hes 1 and Hes 5 mutant mice. Hear Res 170(1-2):22-31.

ZINE A, VAN DE WATER TR, DE RIBAUPIERRE F (2000) Notch signaling regulates the pattern of auditory hair cell differentiation in mammals. Development 127(15):3373-83.

ZINE A, AUBERT A, QIU J, THERIANOS S, GUILLEMOT F, KAGEYAMA R, DE RIBAUPIERRE F (2001) Hes1 and Hes5 activities are required for the normal development of the hair cells in the mammalian inner ear. JNeurosci21:47124720.

ZUR LAGE PI, POWELL LM, PRENTICE DR, MCLAUGHLIN P, JARMAN AP (2004) EGF receptor signaling triggers recruitment of Drosophila sense organ precursors by stimulating proneural gene autoregulation. Dev Ce//7(5):687-96.

Published Online: 18th September 2007 


\section{Related, previously published Int. J. Dev. Biol. articles \\ See our Special Issue Ear Development edited by Fernando Giraldez and Bernd Fritzsch at: http://www.ijdb.ehu.es/web/contents.php?vol=51\&issue=6-7}

BMP2/4 and BMP5-8 in jellyfish development and transdifferentiation

Susanne Reber-Müller, Ruth Streitwolf-Engel, Nathalie Yanze, Volker Schmid, Michael Stierwald, Michael Erb and Katja Seipel

Int. J. Dev. Biol. (2006) 50: 377-384

The homeobox gene Msx in development and transdifferentiation of jellyfish striated muscle Sabina Galle, Nathalie Yanze and Katja Seipel

Int. J. Dev. Biol. (2005) 49: 961-967

A life in research on lens regeneration and transdifferentiation. An interview with Goro Eguchi Kunio Yasuda

Int. J. Dev. Biol. (2004) 48: 695-700

Transdifferentiation of corneal epithelium: evidence for a linkage between the segregation of epidermal stem cells and the induction of hair follicles during embryogenesis.

David J Pearton, Corinne Ferraris and Danielle Dhouailly

Int. J. Dev. Biol. (2004) 48: 197-201

A life in research on lens regeneration and transdifferentiation. An interview with Goro Eguchi Kunio Yasuda

Int. J. Dev. Biol. (2004) 48: 695-700

The extracellular matrix in development and regeneration. An interview with Elizabeth D. Hay Robert L. Trelstad

Int. J. Dev. Biol. (2004) 48: 687-694

The biology of feather follicles.

Mingke Yu, Zhicao Yue, Ping Wu, Da-Yu Wu, Julie-Ann Mayer, Marcus Medina, Randall B Widelitz, Ting-Xin Jiang and ChengMing Chuong

Int. J. Dev. Biol. (2004) 48: 181-191

Formation of retinal pigment epithelium in vitro by transdifferentiation of neural retina cells.

M Opas, J R Davies, Y Zhou and E Dziak

Int. J. Dev. Biol. (2001) 45: 633-642

The cytoskeletal effector XPAK1 is expressed during both ear and lateral line development in Xenopus.

$\mathrm{N}$ Islam, L Poitras and T Moss

Int. J. Dev. Biol. (2000) 44: 245-248 